\title{
VIDEIRA 'ITÁLIA' (QQitis vinifera L.) - PRODUÇÃO TARDIA DA UVA COM VARIAÇÕES NO SISTEMA E NA ÉPOCA DE PODA
}

\author{
ANTONIO YOSHIO KISHINO
}

Orientador: Prof. Dr. VLADIMIR RODRIGUES SAMPAIO

Dissertação apresentada à Escola Superior de Agricultura "Luiz de Queiroz", da Universidade de São Paulo, para obtenção do título de Mestre em Fitotecnia.

PIRACICABA

Estado de São Paulo - Brasil

- 1981 - 


\section{AOS VITICULTORES}

OFEREC O

AOS MEUS PAIS

E IRMÃOS

D E D I C 0 


\section{A G R A D E C I MENTOS}

Ao Prof. Dr. Vladimir Rodrigues Sampaio, pela orientação, a mizade e sugestões apresentadas;

Ao IAPAR - Fundação Instituto Agronômico do Paraná, pela oportunidade concedida para realização do curso;

$\bar{A} \quad$ EMBRAPA - Empresa Brasileira de Pesquisa Agropecuāria,pe 1o auxílio financeiro;

$\bar{A}$ Escola Superior de Agricultura "Luiz de Queiroz", da Uni versidade de São Paulo, Piracicaba, SP, pela oportunidade de aperfeiçoamento;

Ao Prof. Dr. Décio Barbin e à Profá. Dra. Clarice Garcia Bor ges Demétrio, pela orientação e colaboração nas análises estatísticas;

Aos Funcionários da Ārea de Agrometeorologia do IAPAR, pela colaboração prestada na tabulação dos dados climatológi$\cos$;

$\bar{A}$ Sra. Neide B. Filet, pela revisão da bibliografia;

E a todos aqueles que, de alguma forma, contribuiram para rea 1 ização deste trabalho. 
LISTA DE TABELAS ........................... vi

LISTA DE FIGURAS ......................... vi

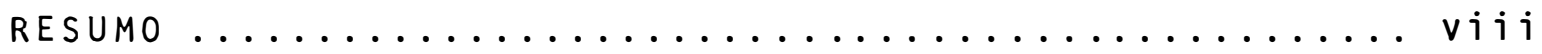

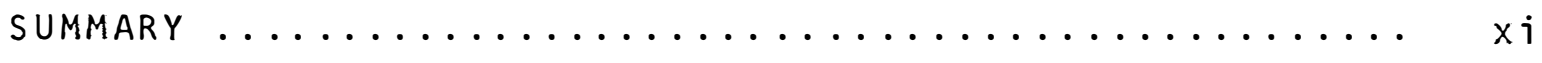

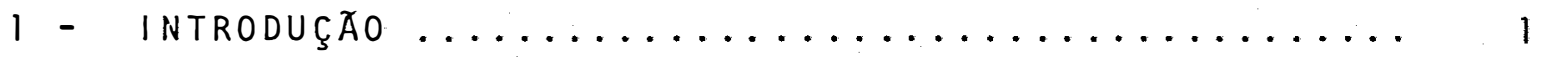

2 - ReVisato de literatura ..................... 4

2.1 - Poda da Videira ................. 4

2.1 .1 - Intensidade da poda ........... 5

2.1 .2 - Epoca da poda ............... 11

2.2 - Dormência e Forçamento da Brotação das Gemas.. 13

2.2 .1 - Dormência ................. 13

2.2.2 - Forçamento da brotação das gemas.. 19

2.3 - Produção de Uvas na Entressafra ......... 25

3 - material e metodos ........................ 30

3.1 - Localização do Experimento .............. 30

3.2 - Cultivar ................... 30

3.3 - Histórico do Pomar ................ 31 
$3.4-$ Clima da Região ................... 32

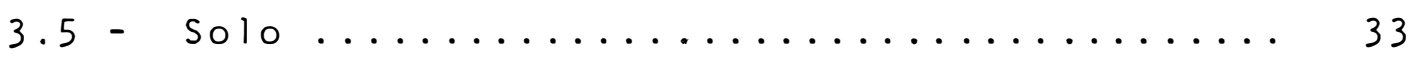

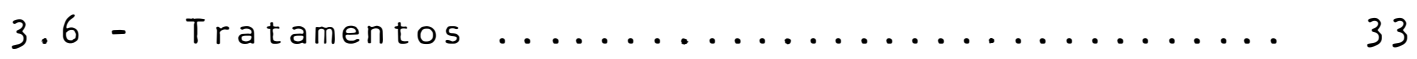

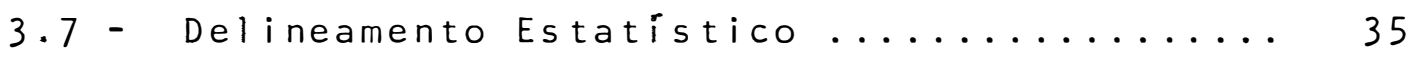

3.8 - Tratos Culturais e Fitossanitärios ...... 35

3.9 - Avaliação dos Parâmetros ............. 36

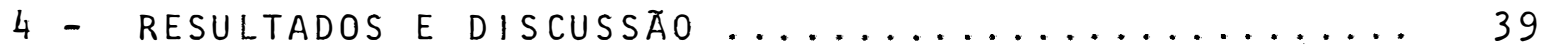

4.1 - Efeitos sobre a Fenologia da Planta e Epoca de Maturação da Uva .............. 39

4.1 .1 - Fenologia da planta............. 39

4.1 .2 - Epoca de maturação da uva ........ 42

4.2 - Efeitos sobre a Porcentagem de Brotação das Gemas ...................... 46

4.3 - Efeitos sobre o Nümero de Cachos Produzidos e Produção por Planta ............ 50

4.3 .1 - Nümero de cachos produzidos ....... 50

4.3 .2 - Produção por planta ............. 51

4.4 - Efeitos sobre o Peso e Comprimento do Cacho. 54

4.4 .1 - Peso do cacho ................. 54

4.4 .2 - Comprimento do cacho ............ 55

4.5 - Efeitos sobre os Parâmetros da Baga ...... 57

4.5 .1 - Nümero de sementes por baga ...... 57

4.5 .2 - Peso da baga .............. 58

4.5 .3 - Comprimento da baga ............. 59

4.5 .4 - Diâmetro da baga ................ 60 
Pāg .

4.6 - Efeitos sobre o Vigor dos Ramos .......... 62

4.6 .1 - Comprimento do ramo ............. 62

4.6 .2 - Diàmetro do ramo .............6 63

4.6 .3 - Número de entrenós por ramo ....... 63

4.6 .4 - Comprimento do entrenó ........... 64

4.7 - Efeitos sobre a Porcentagem de Desfolha... 67

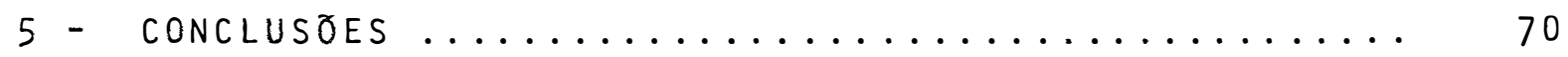

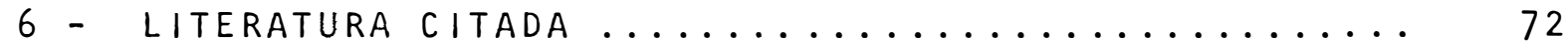

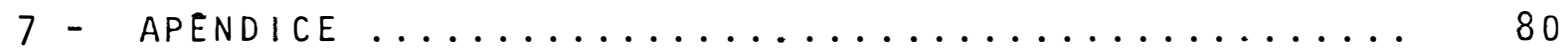




\section{LISTA DE TABELAS}

Pàg

TABELA 1 - Datas da execução dos tratamentos e dados fenológicos das videiras 'Itālia', submetidas a diferentes tratamentos com variações no sistema e época de poda ..........

TABELA 2 - Nümero de dias entre os eventos fenolögicos das videiras 'Itālia', submetidas a diferentes tratamentos com variações no

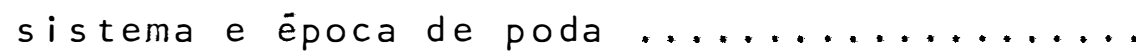

TABELA 3 - Nümero de cachos produzidos e produção por planta das videiras 'Itālia', submetidas a diferentes tratamentos com variações no

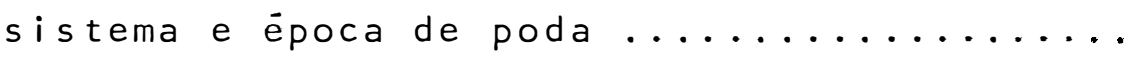

TABELA 4 - Peso e comprimento dos cachos das videiras 'Itälia', submetidas a diferentes tratamen tos com variações no sistema e época de po.

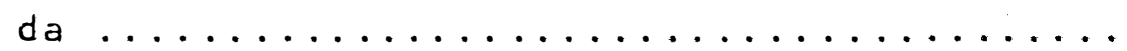

TABELA 5 - Nümero de sementes por baga e peso, comprimento e diàmetro das bagas das videiras 'Itälia', submetidas a diferentes tratamen tos com variações no sistema e época de po

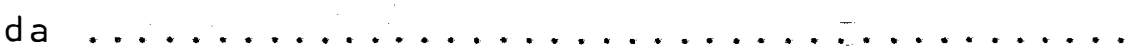

TABELA 6 - Comprimento e diâmetro do ramo, número de entrenós por ramo e comprimento do entrenó das videiras 'Itālia', submetidas a di ferentes tratamentos com variações no sis

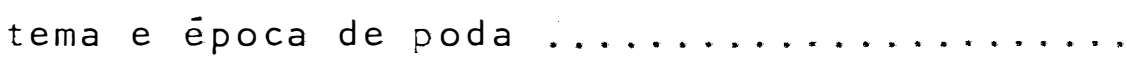


vii.

\section{LISTA DE FIGURAS}

Pàg.

FIGURA 1 - Epoca de maturação do fruto das videiras 'Itālia', submetidas a diferentes tratamentos com variações no sistema e ëpoca

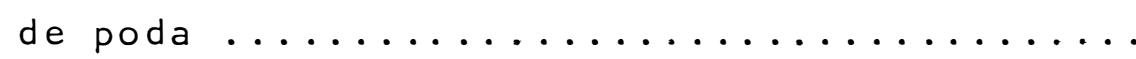

FIGURA 2 - Porcentagem de brotação das gemas das vi deiras 'Itālia', submetidas a diferentes tratamentos com variações no sistema e $\underline{e}$ poca de poda, em diferentes datas de ava

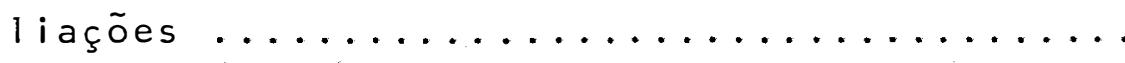

FIGURA 3 - Porcentagem de desfolha das videiras 11tālia', submetidas a diferentes tratamen tos com variações no sistema e ēpoca de poda, em diferentes datas de avaliações.... 
viji.

\title{
VIDEIRA 'ITÁLIA' (Vitis vinifera L.) - PRODUCÃO TARDIA DA UVA COM VARIACÕES NO SISTEMA E NA ÉPOCA DE PODA
}

\author{
ANTONIO YOSHIO KISHINO \\ Dr. Vladimir Rodrigues Sampaio \\ Orientador
}

\section{RES UH 0}

Em experimento instalado no Município de São Miguel Arcanjo, Estado de São Paulo, estudou-se a possibilida de de atrasar o perỉodo de maturação da uva 'Itālia', retar dando o inīcio do ciclo vegetativo, atravēs de variações no sistema e época de poda usuais.

Foram avaliados os seguintes tratamentos:

A - Poda em meados do inverno ; forçamento da brotação das gemas em toda extensão do ramo.

B - Poda antes do inchamento das gemas; forçamento da brotação das duas gemas da extremidade do ramo ; elimina ção dos brotos quando estes apresentavam $20 \mathrm{~cm}$ de comprị mento ; forçamento da brotação das gemas em toda exten são do ramo. 
C - Poda antes do inchamento das gemas; forçamento da brotação das duas gemas da extremidade do ramo; eliminação dos brotos quando estes apresentavam $50 \mathrm{~cm}$ de comprimento ; forçamento da brotação das gemas em toda extensão do ramo.

D - Poda antes do inchamento das gemas; forçamento da brotação das duas gemas da extremidade do ramo; eliminação dos brotos quando estes apresentavam $100 \mathrm{~cm}$ de comprimen to; forçamento da brotação das gemas em toda extensão do ramo.

E - Poda no início do inchamento das gemas; forçamento da brotação das gemas em toda extensão do ramo.

Em videiras de todos os tratamentos, foi rea-

1 izada a poda longa com 8 a 10 gemas. O forçamento da brota ção das gemas foi realizado com emprego da solução de calcio cianamida.

observou-se que o ciclo vegetativo foi mais longo nas videiras podadas em meados do inverno, em relação à quelas podadas mais tardiamente. A uniformidade e a porcenta gem da brotação das gemas aumentaram,à medida que se atrasou a época da poda, independentemente dos tratamentos executados.

A variação no sistema de poda estudada atrasou em 44 dias a maturação da uva, em relação à poda executada em meados do inverno, e, em 16 dias, comparativamente à poda rea 
lizada no inĩcio do inchamento das gemas. A eliminação dos brotos com $20 \mathrm{~cm}$ de comprimento não afetou a produtividade,os parāmetros dos cachos e das bagas e o vigor dos ramos. A eli minação dos brotos com 50 e $100 \mathrm{~cm}$ de comprimento, resultou em prejuízos para os mesmos parāmetros.

A poda executada no início do inchamento das gemas atrasou em 28 dias a maturação da uva, em relação à poda realizada em meados do inverno. A produtividade, o comprimento dos cachos, os parāmetros das bagas e o vigor dos ramos foram equivalentes nas duas épocas de poda estudadas. As videiras podadas em meados do inverno produziram cachos de maior peso.

Tambēm observou-se que a incidēncia de doenças füngicas nos cachos e nas folhas aumentou com atraso no início do ciclo vegetativo da videira, o que, em parte, contribuiu para diminuir o nūmero de cachos produzidos e a produ ção por planta.

A maturação dos ramos foi retardada, com atra so no início do ciclo vegetativo, ficando os mesmos sujeitos aos riscos das geadas. Observou-se, tambēm, maior ocorrēncia de rachadura de bagas, à medida que se atrasou o período de maturação da uva. 


\title{
'ITALIA' GRAPEVINE (vitis vinifera L.) - LATE GRAPE PRODUCTION WITH PRUNING SYSTEM AND TIME VARIATION
}

\author{
Antonio Yoshio Kishino \\ Author \\ Dr. Vladimir Rodrigues Sampaio \\ Advisor
}

\section{SUPMARY}

In an experiment carried out in the county of São Miguel Arcanjo, State of São Paulo, Brasil, it was studied the possibility to delay the 'Italia' grapevine ripening period by retarding the beginning of the vegetative cycle, through variation of the usual pruning system and time.

The following treatments were evaluated:

A - Pruning in the middle of the winter, and forcing the bud sprounting along the whole extension of the twig.

B - Pruning before bud swelling, forcing the sprouting of the two buds at the twig end, removal of shoots when they were $20 \mathrm{~cm}$ long, and forcing the bud sprouting along the whole extension of the twig.

C - Pruning before bud swelling, forcing the sprouting of the two buds at the twig end, removal of shoots when they were $50 \mathrm{~cm}$ long, and forcing the bud sprouting along the whole extension of the twig. 
D - Pruning before bud swelling, forcing the sprouting of the two buds at the twig end, removal of shoots when they were $100 \mathrm{~cm}$ long, and forcing the bud sprouting along the whole extension of the twig.

E - Pruning at the beginning of bud swelling, and forcing the bud sprouting along the whole extension of the twig.

In grapevines belonging to all the treatments cane-pruning with 8 to 10 buds was made. The budbreak was sti mulate using calcium cyanamide solution.

It was observed that the vegetative cycle was

longer in grapevines that were pruned in the middle of the winter, in relation to those pruned later. The bud sprouting uniformity and percentage increased as the pruning time delayed, regardless the treatments.

The variation in the studied pruning system retarded the grape ripening in 44 days, in relation to the pruning made in the middle of the winter, and in 16 days when compared to the pruning made at the beginning of the swelling.

Removal of shoots when they were $20 \mathrm{~cm}$ long did not affect the productivity, the bunch and berry parameters and the twig vigour. Removal of shoots when they were 50 and $100 \mathrm{~cm}$ long caused damage to the same parameters. 
The pruning made in the beginning of the bud swelling retarded the grape ripening in 28 days, in relation to the pruning executed in the middle of the winter. The pro ductivity, the bunch length, the berry parameters and the twig vigour were equivalent in both of the studied pruning time. The grapevines that were pruned in the middle of the winter produced heavier bunches.

It was also observed that fungus diseases in the bunches and leaves increased when the beginning of the ve getative cycle was retarded, what, in part, contributed to decrease the quantity of bunches and yield per plant.

The twig ripenning was retarded, with delay of the beginning of the vegetative cycle, and became subject to frost risks. It was also observed the occurrence of more cracks in the berries, as the grape ripening period was retar ded. 


\section{1 - INTRODUCÃO}

No Brasil, a uva é a terceira fruta mais produ zida, depois da laranja e da banana. Destacam-se entre os principais Estados produtores, o Rio Grande do Sul, São Paulo, Santa Catarina, Paranā, Minas Gerais e Pernambuco (ANUARIO ES TATISTICO DO BRASIL, 1980). No Rio Grande do Sul e Santa Catarina, maior parte da uva produzida é destinada à vinifica ção, enquanto que as produções de São Paulo e Norte do Paranā, destinam-se, principalmente, para consumo "in natura", predominando as uvas 'Niagara Rosada' e 'Itālia'. Neștes Estados, a contribuição da viticultura no desenvolvimento sōcio-econōmico é bastante expressiva. Em especial, a produção de uvas finas para mesa, como a 'Itāija' e, mais recentemente, a 'Rubi Okuyama', é considerada excelente alternativa de renda para os pequenos agricultores. 
No Norte do Estado do Paranā, a uva 'Itālia' è produzida em diferentes épocas do ano. Esta técnica, conheci da como "produção de uvas temporãs", é muito difundida entre os viticultores daquela região. Consiste em produzir uvas na entressafra através da combinação racional das práticas cultụ rais, principalmente, poda e emprego da solução de calciociana mida para estimular a brotação da videira, além do controle de danos das geadas no inverno. Este procedimento tem contribuĩ do para elevar a renda dos produtores. Na região do Vale Médio do São Francisco, também se produz a uva 'Itālia' em dife rentes meses do ano,através das variações na época de poda, com emprego da irrigação.

No Estado de São Paulo, sobressaem como maiores produtores de uva 'Itālia' (Pirovano 65), os Municípios de São Miguel Arcanjo e Pilar do Sul que, em 1980, produziram $47,0 \%$ do total de 1.477 .574 caixas de $8 \mathrm{~kg}$ comercializadas na CEAGESP - Companhia de Entrepostos e Armazēns Gerais de São Paulo (BOLETIM MENSAL CEAgesp, 1980). As produções daquela região, porém, concentram-se entre os meses de janeiro e meados de março, quando os preços são baixos em decorréncia da o ferta de grande quantidade de uva, tornando, muitas vezes, a cultura pouco rentável, devido a o seu elevado custo de produ ção.

- Para a região de São Miguel Arcanjo, onde se verifica ocorréncia de geadas entre início de maio e final de 
agosto, a possível solução para o problema seria atrasar o pe ríodo de colheita para final de março ou abril, quando se observa considerável diminuição na oferta das uvas 'Itālia',

'Niagara' e 'Isabel' e elevação dos preços, na CEAGESP.

Assim, o presente trabalho teve por objetivo es tudar a possibilidade de atrasar o perīodo de maturação da uva 'Itālia', retardando o inīcio do ciclo vegetativo, atravēs de variações no sistema e época de poda usuais. 


\section{2 - REVISÃO DE LITERATURA}

\section{1 - PODA DA VIDEIRA}

A poda da videira compreende a eliminação total ou parcial de diferentes partes da planta (ramos e,excepcio nalmente, o tronco), assim como as partes herbāceas (brotos, fo Ihas, rācimos e outras partes vegetativas). Tem por fim equi librar a produção de frutos e o crescimento vegetativo, regularizar as colneitas em quantidade e qualidade e dar à planta determinada forma de modo a obter maior eficiência nos tratos culturais e fitossanitārios (SOUSA, 1969 ; WINKLER, 1970 ; PU JOL, 1972 ; TICO e TICO, 1972 ; HIDALGO, 1979). A prātica da poda baseia-se nos princípios da fisiologia vegetal.

A videira produz nos ramos de um ano de idade, chamados sarmentos ou bacelos (SOUSA, 1969 ; WINKLER, 1970 ; PUJOL, 1972 ; TICO e TICO, 1972 ; HIDALGO, 1979). 
A intensidade da poda, ou seja, o nūmero de gemas a deixar por ramo ou planta, depende do hábito de frutificação da cultivar e do vigor da planta, ou do sarmento (SOUSA, 1969 ; WINKLER, 1970 ; PUJOL, 1972 ; ALCALDE, 1973 ; HIDALGO, 1979). Quanto ao número de gemas deixados por sarmento, a po da pode ser curta e longa. A poda é curta, quando se deixa uma a três gemas por bacelo e longa, quando se deixa mais de quatro gemas por sarmento. Os bacelos podados curtos são chamados de esporões e aqueles podados longos, de varas. Poda mista é aquela que se faz as podas curta e longa na mesma planta.

Outro aspecto importante a considerar é a época da poda. Quando se faz no inverno chama-se de poda seca ou hibernal e aquela que se faz no verão, durante o crescimen to vegetativo, chama-se de poda verde.

\subsection{1 - Intensidade da Poda}

Nas cultivares que têm gemas frutîferas atē a base do sarmento, geralmente, faz-se a poda curta e naquelas cujas gemas da base do ramo são pouco produtivas, faz-se a po da longa, visando aumentar a produtividade (SOUSA, 1969 ; WINK LER, 1970 ; HIDALGO, 1979). Segundo WINKLER (1970) e HIDALGO (1979), na maioria das cultivares, os räcimos alcançam tamanho e número máximo na parte mediana dos bacelos. 
Em plantas vigorosas, normalmente, os ramos fra cos são podados curtos e aqueles mais vigorosos são podados longos; neste caso, a finalidade dos esporões ē a produção de bacelos para frutificação do ano seguinte. Em videiras fracas, os ramos são podados curtos para revigoramento (SOUSA, 1969 ; WINKLER, 1970 ; TICO e TICO, 1972 ; HIDALGO, 1979). Os bacelos muito fracos, doentes ou em nūmero excessivo são eliminados pela base (SOUSA, 1969).

Geralmente, as plantas e os sarmentos de vigor mediano apresentam gemas bastante frutiferas (SOUSA, 1969 ; WINKLER, 1970 ; PUJOL , $1972 ;$ HIDALGO 1979 ; KISHINO e MASHI MA, 1980) e brotações mais abundantes e uniformes que aquelas ou aqueles excessivamente vigorosos (KISHINO et alii, 1978.b; KISHINO e MASHIMA, 1980). Na poda, portanto, devem ser con servados na planta os bacelos de vigor individual médio.

- Muitos autores relatam que, conservando-se maior nümero de gemas frutīferas por planta, a produção aumenta (WIN KLER, 1970 ; PUJOL, 1972 ; BALASUBRAHMANYAM e KHANDUJA, 1977.b; CAWTHON e MORRIS, 1977 ; LANE, 1977 ; HIDALGO, 1979), mas afe ta a qualidade do fruto (WINKLER, 1970 ; BOLCEV, 1972 ; CAWTHON e MORRIS, 1977 ; SINGHROT et alii, 1977). 0 vigor doS brotos diminui com a poda moderada (BOLCEV, 1972 ; SINGHROT et $a$ Iii, 1977 ; HIDALGO, 1979).

Diminuindo o nūmero de gemas deixado por plan ta, por outro lado, a produção diminui (TOMKINS e SHAULIS, 
1955 ; LIDER et alii, 1973) e o vigor individual dos brotos au menta (WINKLER, 1970 ; PUJOL, 1972 ; TICO e TICO, 1972 ; LIDER et alii, 1973 ; HIDALGO, 1979). Este aumento no vigor resulta não só da poda, mas tambēm da diminuição da colheita (WIN $\underline{K}$ LER, 1970 ; TICO e TICO, 1972 ).

Em videira 'Concord' (Vitis Zabrusca L.), as gemas mais afastadas da base do sarmento são mais frutiferas (PARTRIDGE, 1921 ; MANEY e PLAGGE, 1934). CAWTHON e MORRIS (1977) informam que, conservando-se maior nūmero de gemas por planta, a produção desta cultivar aumenta, mas a qualidade do fruto è prejudicada.

Trabalhando com a videira 'Sultanina' (Vitis vinifera L.), CHANANA e KUMAR (1974) observaram que a poda cur ta com 3 gemas por sarmento proporcionou maior nümero de ca chos e maior produção que as podas com 4 ou 5 gemas. Também constataram que a porcentagem de brotação das gemas, tamanho do cacho e peso e qualidade da baga não foram influenciados por diferentes intensidades de poda estudadas. Estes autores sugerem, para esta cultivar, fazer podá curta com 3 gemas por bacelo.

WINKLER (1970) informa que em videira 'Thomp son Seedless', as gemas frutiferas estão situadas entre 4 ? e 12. gemas e recomenda fazer a poda longa com 10 a 12 gemas. BHUJBAL (1972) relata que as gemas mais frutíferas nessa cultivar encontram-se na parte mediana do sarmento e estas têm 
potencial para produzir cachos maiores. Ele recomenda, para as condições do oeste da India, poda longa com 10 gemas por ramo. BALASUBRAHMANYAM E KHANDUJA (1977.a) sugerem fazer a poda com 10 a 14 gemas por bacelo.

Trabalhando com a videira 'Thompson Seedless', SINGHROT et alii (1977) obtiveram maior nūmero de cachos por planta podando-se os sarmentos com 10 gemas e aumento no peso do cacho e produção total, podando-se com 8 gemas. Com o aumento da quantidade de gemas por ramo, foi notado decréscimo no vigor dos brotos. "Também observaram decréscimo signi ficativo no teor de sōlidos - solúveis totais, sendo que o teor māximo foi verificado naquelas videiras podadas com 6 gemas por ramo, seguidas pelas podas com 4,8 e 10 gemas, respect vamente. Quando os bacelos foram podados com 4 e 6 gemas, 0 teor de sōlidos - solūveis nas bagas foi significativamente mais alto que em poda com 10 gemas. Este prejuízo em qualidade, segundo estes autores, pode ser devido ao aumento da pro dução e conseqüente diluição do açūcar nas bagas.

A videira' 'Itāila' (Vitis vinifera L.) apresen ta gemas frutiferas afastadas da base do sarmento e exige,por tanto, poda longa para frutificação (SOUSA, 1969 ; KISHINO e MASHIMA, 1980). Para a videira 'Rubi Okuyama', mutante da 'Itālịa' com bagas de coloração rosada, KISHINO e MASHIMA (1980) recomendam fazer a poda longa para produção de frutos. 
Na Rūssia, BOLCEV (1972) obteve maior produti vidade da videira 'Itāila' fazendo-se a poda longa com 6 a 8 gemas por ramo. Fazendo-se a poda com 12 gemas ou mais por sarmento, ele observou declínio rāpido no coeficiente de produtividade e, com 20 gemas, este bajxou para 0,26. Tambēm verificou que a qualidade do fruto e o crescimento do broto foram afetados quando se deixou maior nūmero de gemas por planta. Em estudo realizado em Petrolina, PE, NUNES et a $i$ i (1979) obtiveram produções mais altas da videira 'Itāila' fazendo-se as podas mista e longa ( 6 a 10 gemas por vara), não detectando, porém, influēncias dos tipos de poda estudados: nos teores de sólidos - solūveis e de àcidos.

Para favorecer a brotação das gemas nas videiras 'Itāila' submetidas a expiorações intensivas (duas safras num período de 12 meses) que, com freqüência, apresentam pouca disponibilidade de reservas, KISHINO e MASHIMA (1980) re comendam fazer a poda mais curta que a usual (em torno de 5 gemas por vara), mas deixando-se maior nūmero de ramos por planta.

Em videira 'Niagara Rosada' e 'Niagara Branca', SOUSA (1969) recomenda fazer a poda curta com esporões de 2 gemas e, excepcionalmente, em plantas muito vigorosas, fazer a poda longa para aumentar a produção.

Em estudo realizado na India, KHANDUJA et ali $i$ (1976) verificaram que as porcentagens de gemas e brotos fru- 
tíferos em videira 'Beauty Seedless' decresceram linearmente com o aumento do número de gemas deixados por ramo. As prodú ções das videiras podadas com 4 a 6 gemas por ramo foram mais altas que naquelas submetidas à poda mais longa. A maturação do fruto não foi influenciada pela poda. Neste estudo, foi mantido constante o número de gemas deixados por planta, mas foi variado o número de gemas deixados por sarmento.

Em estudo semelhante, tambēm realizado na India, BALASUBRAHMANYAM e KHANDUJA (1977.b) observaram que as porcentagens de brotação das gemas, de brotos frutifferos, de número de cachos e produções em videira 'Gulabi', foram mais elevados quando os ramos foram podados com 12 gemas.

LANE (1977) comparou os efeitos da poda longa com 9 gemas por ramo e curta, com 3 gemas, em 10 cultivares de videira Muscadinia (Vitis rotundifolia, Michx.). Durante os cinco primeiros anos, as videiras 'Cowart', 'Higgins' e 'Hunt' apresentaram produções significativamente superiores, quando podadas com 9 gemas. As produções das outras cultivares foram significativamente aumentadas, em alguns anos, pela utili zação da poda longa. O aumento da produção com o uso da poda longa foi correlacionado com o aumento do tamanho da videira. 


\subsection{2 - Epoca da Poda}

Geralmente, a poda da videira é executada no pe ríodo de repouso hibernal ou no inchamento das gemas (SOUSA, 1969 ; WINKLER, 1970 ; PUJOL , 1972 ; TICO e TICO, 1972 ; HIDALGo, 1979), porēm, em condições do Norte do Paraná (MASHIMA, 1973 ; KISHINo e MASHIMA, 1980) e Vale Médio do São Francisco (SOUSA, 1969 ; SAMPAIO, 1973), a poda é realizada em diferentes meses do ano, dependendo da época em que se pretende coTher a uva.

TICO e TICO (1972) e HIDALGO (1979) sugerem fa zer a poda hibernal em duas épocas. No outono, eliminam-se sarmentos inūteis, em excesso ou doentes, deixando-se täo somente os necessários para formação da cepa e produção.

Segundo WINKLER (1970), PUJOL (1972) e HIDALGO (1979), a poda realizada no outono, antes que as reservas contidas nas folhas se transloquem para os sarmentos e tronco, debilitará a videira, fazendo com que sua brotação seja tar -

dia e ocorra de forma menos vigorosa. Este atraso continuará em todas as demais fases do ciclo vegetativo, inclusive na ma turação do fruto (PUJOL, 1972 e HIDALGO, 1979). O enfraqueci mento da planta e atraso na brotação serão acentuados quanto mais precoce for a poda (WINKLER, 1970 ; PUJOL, 1972 ; HIDALGO, 1979).

Em cultivares de videira Muscadinia, 'Scuppernong' e 'Thomas', LOOMIS (1943) não tem verificado diferença 
significativa na produção entre as plantas podadas logo após a queda das folhas e aquelas podadas antes do início do incha mento das gemas, na primavera.

Para evitar os prejuízos com as geadas tardias, SOUSA (1969), PUJOL (1972), TICO e TICO (1972), HIDALGO (1979) e KISHINO e MASHIMA (1980) recomendam retardar a brotação por meio da poda tardia, fazendo-se no inî́cio do incha mento das gemas.

A poda tardia realizada após a brotação das gemas apresentam os mesmos inconvenientes da poda antecipada, pois, elimina grande quantidade de reservas já mobilizadas pe la planta, situadas nos örgãos que começaram a crescer. 0 de bilitamento da planta e atraso na brotaçäo das gemas são maiores quanto mais tardia a poda e mais desenvolvidos os bro tos (PUJOL, 1972 ; HIDALGO, 1979).

LOOMIS (1943) e WINKLER (1970) relatam que a po da tardia, executada na primavera, causa o chōro ou perda do líquido atravēs dos cortes da poda. Segundo estes autores, as videiras não são afetadas por perda deste líquido. A anālise química realizada por LOOMIS (1943) tem revelado que a seiva consiste praticamente de àgua.

Em condições do Norte do Paranā, segundo o relato de MASHIMA (1973), a videira é submetida a duas podas anual mente: uma em maio e outra em dezembro para se colher a uva em e abril, respectivamente. Hoje, porém, naquela re 
gião, a videira é podada em qualquer mês do ano, visando produção da uva em diferentes épocas do ano (KISHINo e MASHIMA, $1980)$.

SOUSA (1969) informa que, nas āreas semi-āridas do Vale Médio do São Francisco, a poda é executada em janeiro, visando-se colher a uva em abril e torna-se a podar em juiho para se fazer a segunda colheita em outubro.

\section{2 - Dormência e Forgamento da Brotagẽo das Gemas}

\subsection{1 - Dormēncia}

A dormência está, geralmente, associada à suspensão temporāria do crescimento visível da planta. Segundo muitos autores, a dormência é um mecanismo fisiológico que per mite a sobrevivência das plantas, em condições ambientais des favorāveis. Neste período, verificam-se mudanças profundas nas atividades metabólicas das plantas.

De acordo com a literatura, a dormência das plantas é induzida pelas condições de dias curtos, temperaturas baixas e seca.

A dormência das gemas em fruteiras de. clima tem perado tem sido atribuida à presença de inibidores de cresci = mento (SAMISH, 1954 ; WAREING, 1954 ; WAREING, 1956 ; NITSCH, 1963 ; SALISBURY e ROSS, 1969 ; GALSTON e DAVIES, 1972 ; METI 
VIER, 1979), encontrados em maior quantidade nas escamas das gemas (EMMERSON e POWEL, 1978 ; METIVIER, 1979). O hormōnio considerado é geralmente, o ácido abscísico (ABA), e o promotor, a giberelina (WAREING, 1956 ; NITSCH, 1963 ; GALSTON e DA VIES, 1972 ; METIVIER, 1979$)$.

Com a diminuição do comprimento do dia (ou, mais exatamente, com o aumento do comprimento da noite), o nI vel do ácido abscisico nas folhas aumenta, provocando paralização do crescimento apical, redução do número e comprimento dos entrenōs, produção de gemas e abscisão das folhas (WAREING, 1956 ; NITSCH, 1963 ; SALISBURY e ROSS, 1969). A percepção fotoperiōdica é feita pela folha madura (WAREING, 1954; WAREING, 1956 ; SALISBURY e ROSS, 1969 ; GALSTON e DAVIES, 1972 ; METIVIER, 1979). Segundo SALISBURY e ROSS (1969), a dorméncia das gemas, em muitas espécies, é estimulada pélo com primento do dia e pela interação de dias curtos e temperaturas baixas.

A interrupção do perĩodo de repouso se produz na natureza pelas temperaturas baixas de inverno (WAREING, 1956 ; SALISBURY e ROSS, 1969 ; GALSTON e DAVIES, 1972 ; METI VIER, 1979). Os estímulos das baixas temperaturas são recebi dos pelas células meristemāticas das gemas (SALISBURY e RoSS, 1969). Durante este perīodo, o nível das substāncias inibido ras decresce gradualmente, atingindo o mīnimo por ocasião da brotação das gemas. As temperaturas baixas induzem a sinte- 
se de giberelinas pelo sistema de fitocromo (GALSTON e DAVIES, 1972) e também podem induzir diminuição no nível do inibidor, (NITSCH， 1963 ; SALISBURY e ROSS，1969; GALSTON e DAVIES, 1972 ).

A necessidade de temperaturas baixas para a que bra de dormēncia das gemas varia segundo a espécie e a cultivar. MAGOON e DIX (1943) têm verificado que as videiras 'Con cord' e 'Niagara', expostas a temperaturas abaixo de $7,2^{\circ} \mathrm{C}$, durante 200 horas, necessitaram de 87 a 91 dias para iniciaro crescimento e quando expostas durante 1.400 horas àquelas tem peraturas, o mesmo periodo foi reduzido para 23 a 30 dias.

Em estudos realizados no Japão, KUROI constatou que o total de horas de frio entre 0 e $5^{\circ} \mathrm{C}$ exigido pelas videiras 'Neo Muscat', 'Muscat Bailey A' e 'Niagara' é de 1.000 a $1.500,1.500$ e 2.000 horas, respectivamente. Se gundo este autor, a dorméncia das videiras americanas (Vitis Labruscana) é muito mais profunda e longa que a das videiras européias (Vitis vinifera L.).

Nos Estados Unidos, NARAWONGSANONT (1975) observou pronunciadas diferenças no comportamento de cultivares de videira Muscadinia (Vitis rotundifolia, Michx.), submeti das à temperatura de $6,9{ }^{\circ} \mathrm{C}$ por períodos variāveis de 0 a 1.100 horas, com intervalos de 100 horas. Quando as videiras foram colocadas em casa de vegetação aquecida, após o trata mento a frio, 'Magnolia' foi primeira cultivar a brotar, segui 
da por 'Higgins'. As videiras 'Carlos', 'Fry' e 'Noble' foram intermediārias e 'Scuppernong' foi ültima a iniciar a bro tação. Também observou em todas as cultivares estudadas, redução progressiva do tempo requerido para iniciar o rápido crescimento e aumento também progressivo da porcentagem de bro tação, à medida que se aumentou a duração do período de exposição das plantas às baixas temperaturas.

Nas gemas da videira 'Delaware', KUROI (1974) tem constatado diminuição na concentração de substāncias inibidoras no final do periodo de repouso (inicio de fevereiro, no Japão), ao mesmo tempo em que foi verificado rāpido aumento na concentração de substāncias promotoras de crescimento. Em trabalho realizado nos Estados Unidos, EMERSON e POWEL (1978) verificaram diminuição nos níveis do ácido abscísico, durante o esfriamento, nas gemas das videiras 'Beta', 'Concord', 'Dut chess' e 'White Riesling'. Segundo eles, embora o conteúdo de ácido abscísico seja mais alto nas escamas das gemas que nos primórdios, mudanças no nível do ABA durante o esfriamento e durante a brotação das gemas ocorrem somente nos primōrdios. De a cordo com IWASAKI e WEAVER (1977), EMMERSON e POWEL (1978) e IWASAKI (1980), a eliminação da escama da gema apressa a sua brotação.

Decorrido o periodo de baixas temperaturas necessārio à quebra de dorméncia das gemas, o início do crescimento da planta encontra-se limitado pelas condições desfavo- 
ráveis de temperatura do ar, temperatura do solo e disponibilidade de água no solo, entre outros fatores. Segundo muitos autores, o crescimento da maioria das espécies da zona temperada é afetado por temperaturas abaixo de $10^{\circ} \mathrm{C}$, estando a fai xa de temperaturas ótimas para o desenvolvimento situada entre 25 e $30^{\circ} \mathrm{C}$.

A temperatura do solo tambēm influencia a brota ção das gemas da videira. Trabalhando com a videira 'Cabernet Sauvignon', KLIEWER (1975) constatou aumento na porcentagem de brotação das gemas com a elevação da temperatura na região da raiz. Melhor resultado foi obtido a temperaturas de 30 e $35^{\circ} \mathrm{C}$ e menor número de gemas brotadas a 11 e $15^{\circ} \mathrm{C}$. Tambēm ve rificou que a brotação das gemas ocorreram 3 a 8 dias mais cedo a 25 e $30^{\circ} \mathrm{C}$, quando comparadas com a temperatura de $17^{\circ} \mathrm{C}$. Isto, segundo o autor, pode ser explicado, em parte, pe la influência da temperatura sobre a ativação dos hormōnios nas raizes, especialmente a de citocininas. Skene e Kerridge (1972), citados por KLIEWER (1975) têm verificado maior conteūdo de citocininas em raízes crescendo à temperatura de $30^{\circ} \mathrm{C}$ que naquelas crescendo a $20^{\circ} \mathrm{C}$.

$$
\text { No Japão, KUBOTA et alii (1979) submeteram as }
$$

videiras 'Moscatel de Alexandria', envasadas e enxertadas sobre o porta-enxerto HF, à seis diferentes temperaturas de so $10,10,15,20,25,30$ e $35^{\circ} \mathrm{C}$ em dezembro de 1974 e 15 , $18,20,25,30$ e $33^{\circ} \mathrm{C}$ em fevereiro de 1976. Em dezembro, 
foi observada redução no nūmero de dias a té inīcio da brota ção e encurtamento deste perĩodo, com a elevação da temperatú ra. Estas tendēncias não foram verificadas em videiras subme tidas a diferentes tratamentos, em fevereiro. Em dezembro, a porcentagem de brotação foi mais elevado às temperaturas do so10 de 25 e $30^{\circ} \mathrm{C}$, quando se observou aumento da brotação das gemas localizadas na parte basal do ramo. Em fevereiro,as di ferenças entre os tratamentos foram pequenas. O desenvolvi mento dos brotos e das inflorescéncias foi grandemente influenciado por temperaturas do solo de 20,25 e $30^{\circ} \mathrm{C}$, em relação às temperaturas de $10,15,33$ e $35^{\circ} \mathrm{C}$, independentemente das épocas do tratamento (dezembro ou fevereiro).

Trabalhando com a videira 'Delaware', no Japão, KOBAYASHI et alii (1965) verificaram que a aplicação de nitró génio no solo, em janeiro, durante o periodo de repouso, antecipou a brotação das gemas. Tambēm constataram que o desen volvimento inicial dos brotos e dos rácimos aumentou signifi cativamente.

Em condições semi-äridas do nordeste brasileiro, como a região do Vale Médio do São Francisco, um longo pe rỉodo de estiagem faz com que a videira européia perca parcial ou totalmente suas folhas e entre em repouso fisiológico. 0 novo ciclo de produção é iniciado mediante estimulos da poda e da irrigação (SOUSA, 1969 ; SAMPAIO, 1973). 


\subsection{2 - Forçamemto da Brotação das Gemas}

Muitos pesquisadores têm tentado interromper o repouso das gemas da videira com aplicações de produtos quími cos. Os resultados mais satisfatōrios têm sido obtidos com o emprego da solução de calciocianamida (KUROI et alii, 1963 ; MASHIMA; 1973 ; KUROI, 1974 ; IWASAKI e WEAVER, 1977 ; KISHINO et alii, 1978.a ; MORIMOTO e KUMASHIRO, 1978 ; PEREIRA e OLIVEIRA, 1978 ; IWASAKI, 1980). Es te produto contém $63 \%$ de caI ciocianamida, $17 \%$ de hidróxido de cálcio e 12\% de carbono $1 \underline{i}$ vre. A calciocianamida em pó, produto mais empregado, tem $21 \%$ de nitrogénio, sendo $98 \%$ deste total, solūvel em àgua (MALA VOLTA, 1967).

Segundo KUROI (1974), o tratamento das gemas com a solução de calciocianamida não somente diminui o nūmero de horas de frio exigido para a quebra de dormencia, mas tam bēm produz brotação mais vigorosa que aquelas tratadas só com baixas temperaturas. Em videira 'Neo Muscat', ele consta tou que o tratamento das gemas com a calciocianamida apresentou a mesma eficiēncia das baixas temperaturas, enquanto que para 'Muscat Bailey A' e 'Niagara', este tratamento foi equivalente a período de cerca de 1.000 horas de temperaturas abaixo de $5^{\circ} \mathrm{C}$. MORIMOTO e. KUMASHIRO (1978) têm verificado que - efeito da calciocianamida sobre a quebra de dorméncia da videira 'Kioho' foi equivalente a aproximadamente 60 a $65 \%$ das horas acumuladas de temperaturas abaixo de $7,2^{\circ} \mathrm{C}$. 
KUROI (1974) tem observado nas gemas tratadas com a solução de calciocianamida, diminuição nos níveis das substāncias inbidoras e aumento rāpido das substáncias promotoras de crescimento, apōs o tratamento.

De acordo com MORIMOTO e KUMASHIRO (1978), o tratamento das gemas da videira 'Kioho' com tiouréia, nitrato de potāssio ou Merit (adubo foliar) induz brotação significa tiva somente quando misturados com a solução de calciocianamida.

No Japão, KUROI et alii (1963) verificaram que a época mais efetiva para quebrar a dorméncia da videira, atra vés da aplicação da solução de calciocianamida, foi no perīo do intermediārio e próximo ao final da dorméncia (entre final de dezembro e meados de janeiro). MORIMOTO e KUMASHIRO (1978) têm observado que o efeito. da calciocianamida é mais pronun ciado quando o repouso das gemas é pouco profundo, apōs um rā pido período de esfriamento. No Norte do Paraná, no entanto, este tratamento è -realizado quando se pretende forçar o in $\bar{i}$ cio do ciclo da videira, independentemente da época do ano (MASHIMA, 1973 ; KISHINO E MASHIMA, 1980).

Em condições de Niigata, Japão, onde o inverno é severamente frio e longo, KUROI et alii (1963) e KUROI (1974), trabalhando em casa de vegetação, conseguiram antecipar a brotação das gemas da videira 'Koshu' em 15 dias e a colheita em 10 dias, atravēs do tratamento das gemas com a so- 
lução de calciocianimida a 20\%. Em Odawara, onde o inverno é comparativamente mais ameno, o tratamento das videiras 'Gros Colman', cultivadas em casa de vegetação, mostrou notāvel efeito sobre o crescimento. Em condições externas, o tratamen to antecipou a época de maturação da uva 'Delaware'.

PEREIRA e OLIVEIRA (1978) informam que a aplica ção da solução de calciocianamida a $20 \%$ sobre o cordão esporó nado de videiras 'Niagara Rosada' antecipou a brotação e o pe rĩodo de colheita. Também observaram que este tratamento pro porcionou formação de maior nümero e maior desenvolvimento dos brotos, quando comparado à testemunha.

A solução de calciocianamida é preparada, normalmente, com āgua quente duas a três horas antes da aplica ção, usando-se o produto na forma de pó. A concentração usual é de 20\% (KISHINO et alii, 1978.b ; KISHINO e MASHIMA, 1980). As concentrações de 20,30 e $40 \%$ de calciocianamida têm mostrado os mesmos efeitos sobre a porcentagem de brotação da videira 'Itālia' (KISHINO et alii, 1978.a).

0 adubo foliar com al to teor de nitrogēnio, quan do usado em mistura com a solução de calciocianamida, propicia maior uniformidade e aumento no indice de brotação da videira (KISHINO et ali $i$, 1978.a ; KISHINO et alii, 1978.b; KISHINO e MASHIMA, 1980), sendo usado na prāticallo\% de fertilizante fo liar, contendo $30 \%$ de nitrogênio (KISHINO et alii, 1978.b). 
Apesar de não ter verificado aumento significa tivo na porcentagem de brotação, com a adição de espalhante $\underline{a}$ desivo na solução aplicada (KISHINo et azii, 1978.a), seu uso é recomendado por KISHINO et ali $i$ (1978.b) e KISHINO e MASHIMA (1980). Segundo estes autores, a solução torna-se de fácil pincelamento com a adição do espalhante adesivo, sendo a dosa gem usual de 5 a $10 \mathrm{ml} / 10$ litros de solução.

A solução de calciocianamida pode ser aplicada através do pincelamento ou pulverização. O primeiro é o mais difundido entre os produtores de uvas de mesa do Norte do Paranā e tem como vantagem, a possibilidade de aplicação da so1 ução em partes desejadas do ramo (KISHINO et alii, 1978.b). PEREIRA e OLIVEIRA (1978), no entanto, tēm conseguido resultạ dos satisfatōrio, pulverizando a solução de calciocionamida so brenadante sobre o cordão esporonado da videira 'Niagara Rosa da'.

0 efeito do tratamento com a solução de calcio cianamida é 1 imitado à parte da planta ou do ramo tratado (KE ROI et alii, 1963; KUROI, 1974). As aplicações da solução so bre as gemas de base do sarmento,com poda longa, aceleram a brotação destas, eliminando a domināncia apical (KUROI, 1974). Por este motivo, KISHINO et azi $i$ (1978.b) e KISHINO e MASHIMA (1980) recomendam, na safra normal, quando se visa brotação das gemas em toda extensão do ramo, dispensar o tratamento da quelas da extremidade, ou fazer o tratamento logo após a poda. 
Is to porque, a poda, quando longa, estimula brotação das gemas localizadas próximo ao corte e, como conseqüencia, as da base e da porção mediana do ramo ficam inibidas. Há, entre tanto, casos em que se aproveita deste inconveniente. Na safra de uvas "temporãs", somente as duas gemas da extremidade do ramo são tratadas, visando inibir a brotação das restantes, que serão utilizadas na safra seguinte (MASHIMA, 1973 ; KISHINO e MASHIMA; 1980). No inverno, quando houver perigo de ocorrēncia de geada, KISHINO et alii (1978.b) sugerem apli car a solução somente nas gemas de uma das faces do sarmento, ou naquelas da extremidade, visando evitar a perda total das gemas.

Em videira'Itālia', com poda longa, KISHINO et alii (1978.a) verificaram que o pincelamento da solução .... de calciocianamida no ramo todo proporcionou brotação significa tivamente mais alta, comparativamente à aplicação somente nas gemas. KUROI (1974), no entanto, não tem observado diferen ças significativas entre estes tratamentos, realizados em videira' 'Koshu', submetida a poda longa. Segundo ele, o tratamento só do entrenō não produz efeito sobre a brotação. das gemas. Em videira 'Niagara Rosada' submetida a poda curta, PE REIRA e OLIVEIRA (1980) verificaram que o pincelamento da so lução de calciocianamida nas gemas e nos cortes deixados pela poda, foi mais efetivo na antecipação da brotação que os pincelamentos isolados de cortes ou gemas. 
A reaplicação da solução também aumenta a uniformidade e porcentagem de brotação das gemas (KISHINo et ali $i$, 1978.b; KISHINO e MASHIMA, 1980). Estes autores recomendam repetir o tratamento, caso chova no intervalo de 24 ho ras apōs a aplicação de calciocianamida. Quando a brotação ob servada é irregular, KISHINO et alii (1978.b) sugerem reaplicar a solução nas gemas não brotadas.

Maior porcentagem de brotação das gemas também é obtida aplicando-se a solução de calciocianamida em condições de alta umidade relativa e temperatura pouco elevada (KI SHINO et alii, 1978.a). Sendo assim, em dias normais, KISHINO et alii (1978.b) e KISHINO e MASHIMA (1980) recomendam fazer o tratamento das gemas ao amanhecer, ao entardecer e durante a noite. Na época seca, KISHINo et alii (1978.b) sugerem fazer a irrigação por aspersão, uma semana antes e no dia anterior ao tratamento, para corrigir a deficiência hîdrica do solo, a $\underline{u}$ mentar a umidade do ar e umedecer os tecidos da planta.

Colocando-se os tubos de polietileno nos ramos logo após o tratamento das gemas com a solução de calciociana mida e retirando-os três dias-após, KISHINO et alii (1978.a), têm conseguido brotação de $49,9 \%$ das gemas tratadas da vide $\underline{j}$ ra 'Itālia' contra $31,0 \%$ do tratamento controle, sem tubo de polietileno. Resultados semelhantes também foram obtidos por Mashima (1970-1972), citado por KUROI (1974). Esta prātica, cria um microclima de umidade e temperatura elevadas no inte 
rior do tubo. E recomendada por KISHINO et a $i$ i (1978.b) e KISHINO e MASHIMA (1980), quando se pretende estimular a bro tação das gemas em ēpocas frias.

$\mathrm{Na}$ produção de uvas de mesa, em condições do Nor te do Estado do Paranā,a combinação racional da poda e emprego da solução de calciocianamida, tem possibilitado: a) aumento da produtividade; b) melhoria da arquitetura da planta; c) controle da ēpoca de produção; d) abastecimento de uvas de mesa no mercado interno nos meses de entressafra; e) maior renda ao viticultor; e f) escalonamento de produção, que pro picia melhor distribuição de mão de obra durante o ano e redu ção dos riscos de perda da produção pelas condições climāti cas adversas (KISHINO et a $i$ i , 1978.b; KISHINO e MASHIMA, $1980)$

\section{3 - Producão de Uvas na Entressafra}

De a cordo com os dados da CEAGESP - Companhia de Entrepostos e Armazēns Gerais de São Paulo, o período dezembro - março compreende os meses de maior oferta de uva 'I tā lia' - Apēndice 1 - (BOLETIM MENSAL CEAgeSP, 1978/1980). A oferta e a demanda são os principais fatores que determinam o preço. Sendo assim, produzindo-se uvas entre abşil e novem bro, quando a oferta de uvas de mesa (inclusive a de uvas 'Nia gara' e 'Isabel'), é relativamente pequena, pode-se obter pre 
ços mais compensadores e aumentar a renda do produtor.

No Norte do Paranā, atualmente, a uva 'I tālia' é produzida principalmente no perīodo de entressafra, antecipando simplesmente a época de colheita ou fazendo-se duas safras anuais ou trés safras a cada dois anos. Esta prātica, cọ nhecida como "produção de uvas temporãs", é otbtida através da combinação racional das prāticas culturais - principalmente a poda e a solução de calciocianamida (para estimular a brota ção das gemas) - e o controle dos danos da geada (KISHINO e MASHIMA, 1980).

0 primeiro resultado prático da produção de uvas na entressafra, obtido no Norte do Paranā, foi relatado por MASHIMA (1973). Atravēs do tratamento das gemas da vide ra 'Itāilia' com a solução de calciocianamida, o iñ̂́cio da co Theita da uva foi antecipado em um més, o que, na safra 1971/ 72, possibilitou aumentar em cinco vezes a renda bruta do vinhedo. Jā, a partir de 1971, os técnicos da Cooperatí va Agricola de Cotia (CAC) realizavam estudos visando obten ção de duas safras anuais da uva 'Itālia', no Estado de São Paulo e Norte do Paranā. Naquela época, foi adotado o seguin te esquema: 1. safra: poda em maio e colheita em dezembro; e 2. safra: poda em dezembro e colheita em abril (MASHIMA, 1973). Hoje, porēm, a poda é executada em qualquer més do ano para produzir uvas em diferentes ēpocas (KISHINO e MASHIMA, 1980). 
Para possibilitar duas colhejtas num periodo de 12 meses, foi introduzida variação no sistema de poda (MA SHIMA, 1973). Quando se visa a produção na época normal (dezembro a março) ou antecipação da colheita das uvas 'Itália' e 'Rubi Okuyama', faz-se a poda longa com 6 a 10 gemas, estimulando-se a brotação das gemas com a solução de calciociana mida em toda extensão do ramo. Para se produzir uvas "temporãs", faz-se a poda longa com 8 a 12 gemas, estimulando-se a brotação somente das duas da extremidade. Na poda seguinte (para produzir novamente na época normal), eliminam-se os ramos que já produziram, deixando-se 6 a 10 gemas remanescentes e reduzindo o nūmero de sarmentos por planta (KISHINO e MASHI MA, 1980).

Segundo KISHINO e MASHIMA (1980), o sucesso da produção de uvas na entressafra, basicamente, depende da:

a) implantação do pomar numa região macroclimática favorável e dentro desta, num topoclima propício ao desenvolvimento da videira e b) adequação dos tratos culturais e fitossanitários ao tipo de exploração (intensivo ou não) e às condições ambientais predominantes em diferentes fases do ciclo vegetativo da videira. De acordo com estes autores, deve-se adotar as práticas que favoreçam o acūmulo de substāncias de reserva na planta, o que é imprescindível para manutenção da produ tividade do pomar e qualidade do fruto. Caso contrārio, em pouco tempo, a videira apresentará sinais de esgotamento, sen 
do os mais tîpicos, a brotação deficiente e irregular, cresci mento e desenvolvimento fraco, produtividade baixa e cachos e bagas pequenos.

Na região norte do Paranā, a uva 'Itālia'é tam bém produzida em casa de vegetação de polietileno, principalmente quando o ciclo vegetativo coincide com o período de inverno (MASHIMA, 1973 ; Kishi, 1971, citado por KUROI, 1974 ; KISHI NO e MASHIMA, 1980). Esta prātica apresenta o inconveniente de diminuir a luminosidade no seu interior, propiciando a for mação de gemas muito fracas e plantas com pequena quantidade de substāncias de reserva (MASHIMA, 1973). Neste tipo de exploração, KISHINO e MASHIMA (1980) não recomendam a produção em casa de vegetação de duas safras consecutivas. Apōs a prọ dução, segundo estes autores, as videiras devem ser submeti das à poda de rejuvenescimento, visando formação de ramos e a cūmulo de substāncias de reserva (portanto, sem visar a produ ção ) .

Nas regiões mais frias, onde as condições de inverno não permitem dois ciclos anuais da videira, KISHINO e MASHIMA (1980) sugerem adotar as prāticas que atrasam a época de maturação da uva, produzindo assim na entressafra. São as seguintes: a) evitar a queda prematura das folhas através dos tratamentos fitossanitārios; b) retardar a brotação por meio da poda tardia; c) deixar na planta maior nūmero de ca chos que o normal; e d) ensacamento dos cachos com papel de 
jornal, duplo.

$$
\text { SOUSA (1969) e SAMPAIO (1973) informam que em }
$$

condições semi-āridas do Nordeste do Brasil, hā possibilidade de se obter duas safras anuais de uva, o que permitiria aten der a demanda desta fruta no periodo de entressafra das regiões tradicionalmente produtoras do país. 


\section{3 - MATERIAL E MÉTODOS}

\section{1 - LoCAlizAcÃo do EXPERIMENTO}

O ensaio foi conduzido num pomar comercial de vi deira 'Itālia', localizado no Município de São Miguel Arcanjo, Estado de São Paulo, latitude $23^{0} 50^{\prime} S$, longitude $47^{\circ} 54^{\prime} W$ de Greenwich e altitude de 700 metros acima do nivel do mar.

\section{2 - Cultivar}

Foi utilizada a videira 'Itālia' (Bicane x Moscate 1 de Hamburgo), predominante na região. Trata-se de uma cultivar de uva fina para mesa que, nas condições de São Miguel Arcanjo, completa o ciclo produtivo (brotação-maturação) em aproximadamente 150 dias. Suas plantas são vigorosas e muito 
produtivas, chegando a produzir facilmente $3 \mathrm{~kg} / \mathrm{m}^{2}$. Exige poda longa para frutificação. E suscetĩvel ã antracnose, mîldio e oídio, necessitando de um programa efeciente de controle às doenças. Seus cachos são grandes (500 a $1.500 \mathrm{~g})$, cōnicos e compactos, exigindo desbaste das bagas. Os pedicelos prendem firmemente as bagas, proporcionando resisténcia à desgrana. Suas bagas são de coloração verde-amarelada quando maduras; grandes ( 8 a 14 g) ; elipsóide alongadas ; de polpa carnosa e com leve aroma moscado. Os frutos apresentam resisténcia ao transporte e à conservação. Na fase pré-amolecimento da baga, é suscetível à escaldadura e na fase pōs-amolecimento, as bagas racham, principalmente, quando chove apōs uma estiagem ou quando o período de chuvas é prolongado.

\section{3 - HISTÓRICO DO POMAR}

0 pomar foi implantado em julho de 1975, com o plantio do porta-enxerto '420 A' (V. berlandieri × V. riparia). A enxertia foi realizada, em julho de 1976, pelo método de garfa gem a meia-fenda no topo, a $10 \mathrm{~cm}$ do solo, e as videiras condu zidas em sistema de latada. 0 espaçamento adotado é de 4 m en tre 7 inhas e $3 \mathrm{~m}$ entre plantas.

Na safra anterior (1979 180$)$, o referido pomar apresentou produtividade de $24.800 \mathrm{~kg} / \mathrm{ha}$, sendo a colheita conclūida no dia 12/03/80. Apōs o término da colheita, foram rea 
lizadas duas pulverizações com calda bordalesa, visando conser var as folhas na planta por maior periodo possivel e, assim,ob ter maior acūmulo de substāncias de reserva na planta. Esta prātica é um procedimento normal naquele pomar. A queda das fo lhas teve início em meados de maio e no final de junho jà se observava a desfolha completa. Em abril foi realizada uma adu bação de reposição e em julho, uma bāsica.

\section{$3: 4$ - Clima da Região}

Segundo sistema de Köeppen, o clima da região é sub-tropical do tipo cfa. Apresenta temperatura média anual de $18,6^{\circ} \mathrm{C}$, ocorrēncia de geadas entre final de maio e agosto, pre cipitação pluvial anual em torno de $1.250 \mathrm{~mm}$ e inverno seco.

Para registrar a temperatura e a umidade relati va do ar do período de condução do experimento, foi instalado no local um termohigrógrafo "Fuess", devidamente acondicionado dentro do abrigo termométrico, a $1,5 \mathrm{~m}$ do solo, orientado na di reção norte-sul. Também foi instalado um pluviōmetro para medir as precipitações ocorridas. Os dados de temperatura, umidade relativa do ar e precipitação pluvial, registrados naquele período encontram-se no Apēndice 2. 


\section{$3.5-$ Solo}

o solo do local onde foi implantado o experimen to está classificado como "Latossol vermelho escuro-orto" (CEN TRO NACIONAL DE ENSINO E PESQUISAS AGRONOMICAS. Comissão de So$105,1960)$.

Por ocasião da implantação do experimento, foram coletadas amostras de solo para caracterização quĩmica e física nas camadas de 0 a $20 \mathrm{~cm}, 20$ a $40 \mathrm{~cm}$ e 40 a $60 \mathrm{~cm}$ de profundidade. A anālise foi efetuada pelo laboratório de solos da Fundação Instituto Agronōmico do Paranā (IAPAR), em Londrina, PR. Os resultados analîticos são apresentados no Apēndice 3 .

\section{6 - Tratamentos}

Foram avaliados os seguintes tratamentos:

A - Poda em meados do inverno; forçamento da brotação das ge mas em toda extensão do ramo.

$B$ - Poda antes do inchamento das gemas ; forçamento da brota ção das duas gemas da extremidade do ramo; eliminação dos brotos quando estes apresentaram $20 \mathrm{~cm}$ de comprimento ; forçamento da brotação das gemas em toda extensão do ramo.

C - Poda antes do inchamento das gemas; forçamento da brota ção das duas gemas da extremidade do ramo; eliminação dos brotos quando estes apresentavam $50 \mathrm{~cm}$ de comprimento; forçamento da brotação das gemas em toda extensão do ramo. 
D - Poda antes do inchamento das gemas; forçamento da brota ção das duas gemas da extremidade do ramo; eliminação dos brotos quando estes apresentavam $100 \mathrm{~cm}$ de comprimento; forçamento da brotação das gemas em toda extensão do ra mo .

E - Poda no início do inchamento das gemas ; forçamento da brotação das gemas em toda extensão do ramo.

Em plantas de todos os tratamentos foi realizada a poda longa com 8 a 10 gemas. A poda executada em meados do inverno correspondeu à época em que a maioria dos produto res da região realizou a poda naquele ano.

O forçamento da brotação das duas gemas da ex tremidade do ramo, nas plantas dos tratamentos B, C e D, teve por objetivo inibir a brotação das gemas localizadas nas porções basais e medianas dos sarmentos e assim retardar o início da brotação das gemas remanescentes. A quebra da dormēncia foi realizada com a aplicação da solução de calciocianamida lo go apōs a execução da poda ou eliminação dos brotos. A solução de calciocianamida, a $20 \%$, foi preparada momentos antes da aplicação com āgua quente e pincelada nos ramos conforme indicado nos tratamentos. Na solução foi adicionado espalhante adesivo. Nas videiras submetidas ao tratamento $A$, devido à ocorréncia de temperaturas baixas apōs a execução da poda *(Apêndice 2), fọ ram colocados tubos de polietileno nos ramos logo depois do tra tamento das gemas com a solução de calciocianamida; os mesmos fo- 
ram retirados 8 dias apōs. Nos demais tratamentos, a solução foi pincelada nos ramos observando-se as condições favoráveis de aplicação, sem porēm usar os tubos de polietileno.

\section{7 - Delineamento Estatístico}

o experimento foi delineado em blocos ao acaso, com 4 repetições e uma planta por parcela. Foram feitas anāli ses dos resultados obtidos pelo teste $F$ e comparações das médias pelo teste de Tukey.

\section{8 - Tratos Culturais e Fitossanitários}

Foram realizados os normalmente dispensados no pomar onde foi implantado o experimento.

Apōs a avaliação da porcentagem de brotação das gemas, aos 35 dias do tratamento com a solução de calciocianami da, foi eliminado o excesso de brotos, deixando-se 3 ou 4 bem distribuídos no ramo.

Aproximadamente uma semana antes da floração,ou seja, quando os brotos apresentavam de 17 a 18 folhas, foi rea lizado o desponte dos ramos. Todos os brotos secundārios foram eliminados parcialmente deixando-se uma folha.

Para permitir formação de bagas perfeitas e maio res, foi realizado o desbaste, eliminando-se aquelas em exces- 
so e "inviāveis", com o uso de tesouras apropriadas. Durante o desenvolvimento do fruto, também foram eliminadas as bagas doen tes e rachadas.

Visando prevenir a escaldadura das bagas, na fä se pré-amolecimento das mesmas, os cachos foram protegidos com papel jornal. Após o amolecimento, esse papel jornal foi subs tituîdo por papel impermeàvel, que permaneceu atē a colheita.

Durante o ciclo vegetativo da videira foram rea lizados dois tratamentos fitossanitārios semanais, utilizandose fungicidas a base de Benomyl e Maneb até a' floração e calda bordalesa após a frutificação. Apōs o término da colneita, fó ram realizadas mais duas pulverizações com calda bordalesa visando conservar as folhas.

\section{9 - Avaliação dos Parámetros}

Por ocasião da eliminação dos brotos da extremi dade do ramo, nos tratamentos B, C e D, foram avaliados o nū mero de brotos, comprimento médio do broto, nūmero médio de fo Thas por broto e peso da matéria seca dos brotos eliminados por planta (Apēndice 4). Para a avaliação do comprimento e nümero de folhas por broto, foram amostrados, a acaso, 10 brotos por parcela. Para determinação do peso da matēria seca, todos os brotos eliminados foram inicialmente secados ao ar livre (na sombra) e posteriormente, cortados em porções menores e coloca 
dos em estufa a $80^{\circ} \mathrm{C}$ até peso constante.

Tambēm foram avaliados: a) fenologia da planta; b) época de maturação da uva; c) porcentagem de brotação das gemas ; d) nūmero de cachos produzidos e produção por planta; e) peso e comprimento do cacho; f) parāmetros da baga; g) vigor dos ramos e h) porcentagem de desfolha. Com relação aos eventos fenolōgicos, foram anotados o iñ̃cio e o fim da brotação, da floração e da maturação para cada tratamento estudado. 0 ponto de maturação considera do prōprio para colheita foi quando as bagas apresentavam $15 \%$ de sōitidos-solūveis.

Para determinação da porcentagem de brotação, fez-se as contagens de todas as gemas tratadas com a solução de calciocianamida e,posteriormente, do nūmero de gemas brotadas, aos $7,14,21,28$ e 35 dias do tratamento. Para efeito de comparações, os dados foram transformados em porcentagem.

A produção total por planta foi obtida pesandose os cachos, individualmente (com o que se obteve tambēm o nū mero de cachos produzidos), ocasião em que tambēm foi medido o comprimento do cacho (base do pedūnculo até a extremidade do cacho).

Para determinações dos parāmetros da bàga (nūme ro de sementes, peso, comprimento e diāmetrol, foram coletadas 20 bagas ao acaso da porção mediana do cacho. Todos estes parâmetros foram obtidos dessas bagas. 


$$
\text { o vigor do ramo e a porcentagem de desfolna fo- }
$$
ram avaliados em 10 ramos representativos, marcados em cada parcela. No dia 13/06/81, foram avaliados o comprimento e dià metro do ramo (maior diàmetro do segundo entrenó), nūmero de entrenōs por ramo e comprimento do entrenō. A porcentagem de desfolha foi avaliada a cada 14 dias a partir do dia 02/05/81, até a queda completa das folhas. 


\section{4 - RESULTADOS E DISCUSSÃO}

\section{1 - Efeitos sobre a Fenologia da Planta e Época de Matu- RAGÃO DA UVA}

\subsection{1 - Fenologia da Planta}

As datas de execução dos tratamentos e os even tos fenológicos das videiras 'Itālia', submetidas a diferentes tratamentos com variações no sistema e êpoca de poda, encontram-se na Tabela 1 .

Nas plantas dos tratamentos $A$ e $E$, onde houve variação na ēpoca da poda, foram podadas nos dias 03/08 e 29/09/80, respectivamente. Nos tratamentos B, C e D, onde se estudou os efeitos da variação no sistema de poda, as vi deiras foram podadas no dia $77 / 08 / 80$ e a eliminação dos brotos 
da extremidade do ramo foi executada nos dias 28/09, 09/10 e 26/10/80, quando os brotos a presentavam 18,6, 48,4 e 95,4 cm de comprimento, respectivamente (Tabela 1 e Apéndice 4).

Nas videiras submetidas aos tratamentos B, C e D, a brotação das gemas da extremidade do ramo inibiram o abrolhamento daquelas localizadas nas porções basal e mediana, o que permitiu retardar o inicio do ciclo vegetativo. Segundo MASHIMA (1973) e KISHINO e MASHIMA (1980) este procedimento é utilizado no Norte do Paranā para produção de uvas "temporãs." Apōs a colheita das uvas produzidas nos brotos das extremidades dos ramos, estes são eliminados e as gemas remanescentes são estimuladas visando a segunda produção, num perīodo de 12 meses.

Considerando-se as datas intermediārias do iñ cio e fim de cada evento fenológico, observou-se que as plantas do tratamento A necessitaram de 26 dias para iniciar a bro tação, enquanto que as do tratamento $D$ necessitaram de apenas 12 dias. Para os tratamentos B, E e C , este período foi de 20 , 20 e 16 dias, respectivamente (Tabela 2). Aparentemente, este período foi mais influenciado pelas condições ambientais que pelos tratamentos executados, provavelmente, porque as plantas apresentavam nīvel relativamente alto de substāncias de reserva. Este resultado pode ser explicado pela ocorréncia de baixas temperaturas apös a realização da poda no tratamento A e elevação da temperatura, à medida que se atrasou a po- 
da definitiva (Apēndice 2). Segundo muitos autores, as plantas se desenvolvem pouco nas temperaturas abaixo de $10^{\circ} \mathrm{C}$, de vido à influéncia negativa dos mesmos sobre as atividades fisiológicas. A temperatura ótima para o desenvolvimento estaria entre 25 e $30^{\circ} \mathrm{C}$. Acredita-se que a temperatura do solo tambēm tenha contribuĩdo para aumentar o nūmero de dias neces sārio para iniciar a brotação. KLIEWER (1975) verificou ante cipação da brotação da videira 'Cabernet Sauvignon', para tem peraturas entre 25 e $30^{\circ} \mathrm{C}$ na zona das raîzes, comparativamente ao nível de $11^{\circ} \mathrm{C}$. KUBOTA et a zii (1979) tambëm observaram re dução no nūmero de dias, até o inīcio da brotação, com a elevação da temperatura do solo. Segundo eles, as temperaturas do solo de 20 a $30^{\circ} \mathrm{C}$ favoreceram majs o desenvolvimento dos brotos.

o período brotação - floração para as plantas. do tratamento A tambēm foi mais 1ongo (52 dias), em contraste ao dos demais tratamentos, que apresentaram períodos variando de 33 a 35 dias. Provavelmente, as temperaturas do ar e do solo tenham contribuído mais efetivamente para obtenção deste resultado, que os efeitos dos tratamentos estudados.

Com relação ao perīodo floraçäo - maturação, as diferenças entre os tratamentos foram menos evidentes. Estes períodos para os tratamentos A, B , C D e F foram, respec tivamente, de 118, $109,111,109$ e 115 dias. 
os ciclos produtivos (brotação - maturação) das plantas dos tratamentos A, B, C, D e E foram, respectivamen te, de $170,142,146,144$ e 148 dias. No tratamento A, sem dūvida, a brotação mais lenta e o florescimento tardio, contribuiram para aumentar o ciclo produtivo.

\subsection{2 - Epoca de Maturação da Uva}

o período de maturação da uva, em videiras 'Itấ Tia' submetidas a diferentes sitemas e épocas de poda, encontra-se na Tabela 1.

Considerando-se a data intermediāria do início e fim de cada evento fenológico, constatou-se que o tratamento D atrasou em 44 dias a maturação da uva, quando compara da à poda realizada em meados do inverno e, em 16 dias, quando comparada à poda tardia, realizada na fase do inchamento das gemas (Figura 1).

A poda realizada no início do inchamento das ge mas atrasou em 28 dias a maturação da uva, em relação à poda executada em meados do inverno.

Na avaliação feita no dia $01 / 02 / 81$, as bägas das videiras submetidas aos tratamentos A, B, C, D e E apresentavam, respectivamente, $13,6,11,0,8,2,5,5$ e $9 \underset{\div}{9}, 8 \%$ de sōlidos - solūveis, o que mostra a existēncia de diferenças na maturação, nos diferentes tratamentos estudados. 
43.

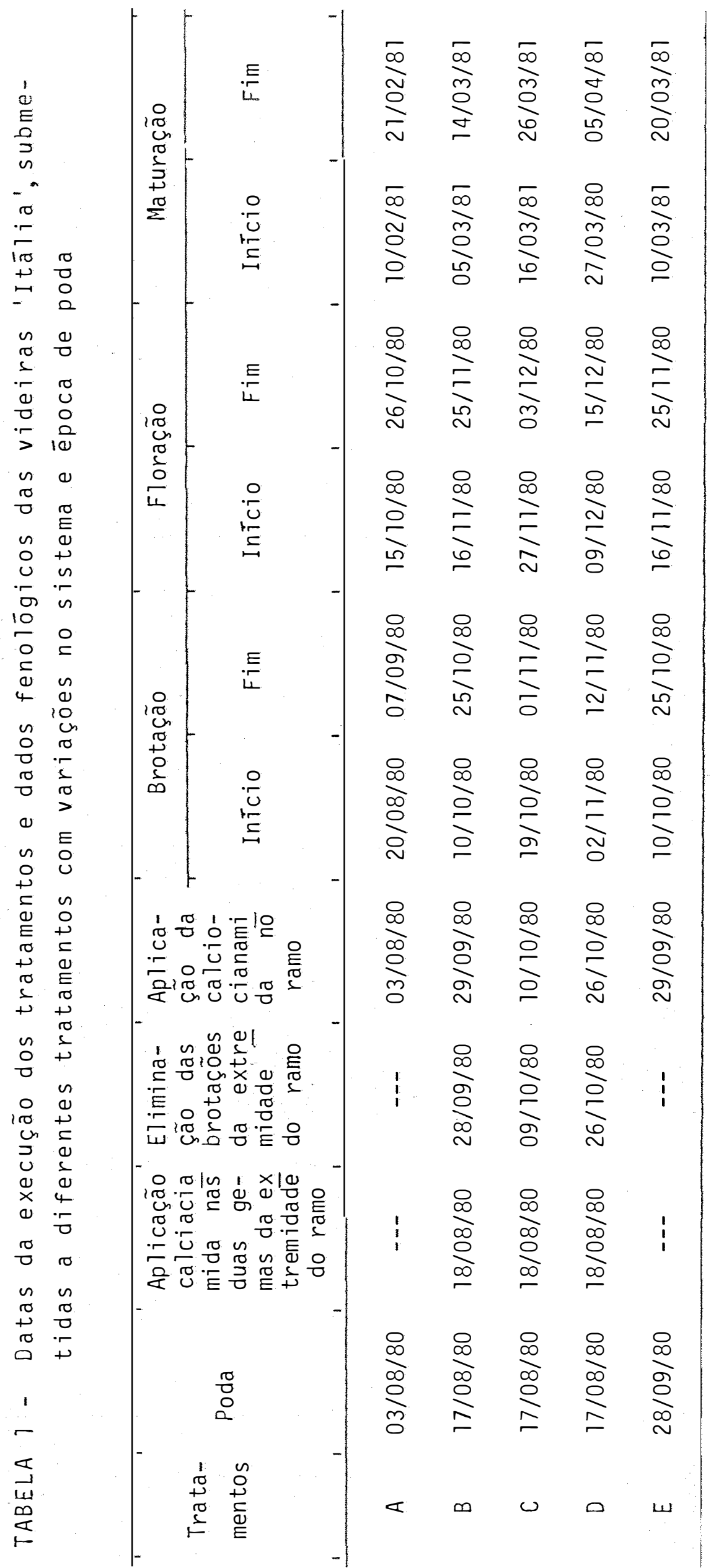


TABELA 2 - Nümero de dias entre os eventos fenolōgicos das videiras 'Itāila', submetidas a diferentes tratamentos com variações no sistema e ēpoca de pó da

\begin{tabular}{ccccc}
\hline $\begin{array}{c}\text { Trata- } \\
\text { mentos }\end{array}$ & $\begin{array}{c}\text { Aplicação cal } \\
\text { ciocianamida- } \\
\text { brotação } \\
\text { (dias) }\end{array}$ & $\begin{array}{c}\text { Brotação- } \\
\text { floração } \\
\text { (dias) }\end{array}$ & $\begin{array}{c}\text { Floração- } \\
\text { maturação } \\
\text { (dias) }\end{array}$ & $\begin{array}{c}\text { Brotação- } \\
\text { maturação } \\
\text { (dias) }\end{array}$ \\
\hline A & 26 & 52 & 118 & 170 \\
B & 20 & 33 & 109 & 142 \\
C & 16 & 35 & 111 & 146 \\
D & 12 & 35 & 109 & 144 \\
E & 20 & 33 & 115 & 148 \\
\hline
\end{tabular}




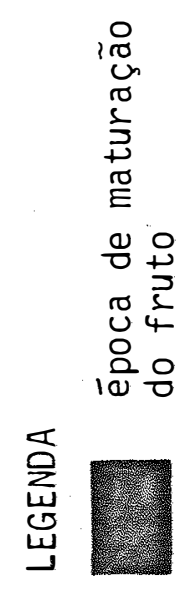

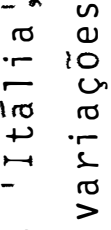

4

음
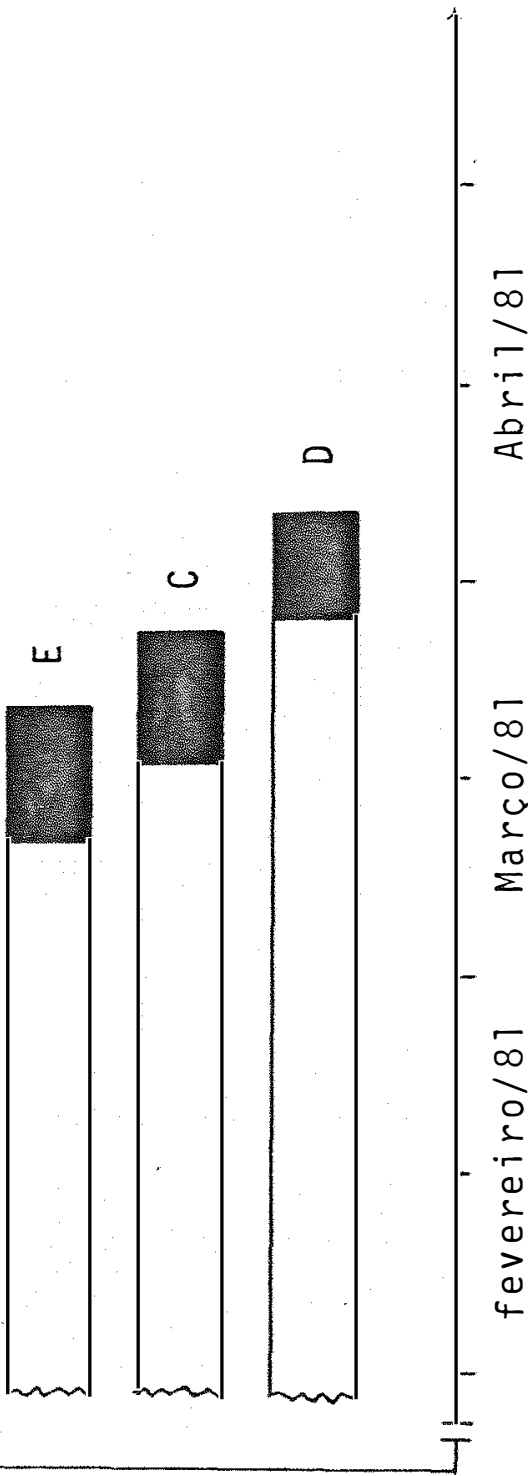

n

¿ E

$\begin{array}{cc}1 & 0 \\ 0 & 0\end{array}$

$>\quad 0$

n

O

$\begin{array}{lll}0 & 1 & \\ + & 0 & 0 \\ 2 & 1 & 0 \\ 4 & 1 & 0\end{array}$

응 $\stackrel{\infty}{+} \frac{0}{0}$

10 बे

ư 40

$\overbrace{+}^{5}$

$\begin{array}{lll}10 & 0 & 0\end{array}$

E

임

$\sigma \stackrel{n}{\pi}$

O

ㄴํ जे 웅

I

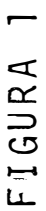




\section{2 - Efeitos sobre a Porcentagem de Brotagão das Gemas}

A porcentagem de brotação das gemas das videiras 'Itālia', submetidas a diferentes tratamentos com varia ções no sistema e época de poda, estā apresentada na figura 2.

observou-se maior uniformidade e maior porcenta gem de brotação das gemas, à medida que se atrasou a época da poda definitiva, independentemente dos tratamentos executados. Em ordem decrescente, os melhores resultados foram observados nos tratamentos D, C, E, B e A, respectivamente.

As plantas do tratamento A não apresentaram ne nhum broto até o 149 dia do tratamento com calciocianamida; aos 21 dias apresentaram apenas $21,2 \%$, aos 28 dias, $40,1 \%$ e aos 35 dias, $53,7 \%$.

As videiras do tratamento $E$ apresentaram porcentagens de brotação ligeiramente superiores àquelas do trá tamento $B, \operatorname{com} 0,1,5,0,75,5,79,6$ e $79,6 \%$, respectiva mnete, aos $7,14,21,28$ e 35 dias após o tratamento para a quebra de dorméncia. As plantas do tratamento B apresentaram $0,1,3,4,64,0,73,3$ e $75,0 \%$ de brotação, respectivamente, aos $7,14,21,28$ e 35 dias.

Nas plantas do tratamento C observou-se, respec tivamente, aos $7,14,21,28$ e 35 dias do tratamento com calciocianamida, $0,5, \uparrow 58,6,80,7,84,7$ e $84,7 \%$ de brota ção. No tratamento $D$, apesar do tratamento drástico, as videiras apresentaram maior uniformidade e porcentagem de brota 
ção ; 14 dias apōs, as plantas jā apresentavam $86,7 \%$ de brotação e apōs 21 dias, $93,2 \%$.

os resultados conseguidos concordam com os obtidos por MAGOON e DIX (1943) e NARAWONGSANONT (1975), que tēm observado diminuição progressiva no nūmero de dias necessārios para o início do crescimento apōs a poda, à medida que o nūme ro de horas de baixas temperaturas foi satisfeito. Segundo KUROI (1974) e EMMERSON e POWEL (1978), no final do período de dormēncia, os nîveis de substāncias inibidoras de crescimento diminuem e os de promotoras aumentam. KUROI et alii (1963) in formam que o tratamento das gemas com a solução de calciocianamida é mais efetivo no perīodo intermediārio e prōximo ao fị nal do período de dorméncia, o que explica, em parte, os resultados obtidos. MORIMOTO e KUMASHIRO (1978) também informam que o efeito da caciocianamida $\bar{e}$ mais pronunciado quando o repouso das gemas è pouco profundo, apōs um período de temperaturas baixas.

Outra possível explicação para o resultado se ria a influência do ambiente, principalmente, da temperatura so bre as atividades fisiológicas da planta. De acordo com muitos autores, a temperatura ōtima para o crescimento das plantas estā situada entre 25 e $30^{\circ} \mathrm{C}$. No período entre o tratamento das gemas com a solução de calciocianamida e o fim da brotação das videiras do tratamento $A$, foram registradas temperaturas médias aquém da considerada ótima, enquanto que o mesmo perĩo 
do para as plantas dos tratamentos B, C, D e E coincidiucom temperaturas mais elevadas (Apēndice 2).

Outro fator que pode ter contribuido para obten ção deste resultado é a temperatura do solo. Este dado não foi coletado, mas presume-se que à medida que se elevou a tem peratura do ar, também se tenha elevado a temperatura do solo. Segundo KLIEWER (1975) e KUBOTA et alii (1979), dentro de certos limites, a elevação da temperatura do solo aumenta a porcentagem de brotação da videira.

Os tratamentos mais drāsticos ( $C$ e $D$ ) não afetaram a porcentagem de brotação como era de se esperar, prova velmente, porque as plantas continham nível relativamente ele vado de substancias de reserva. 


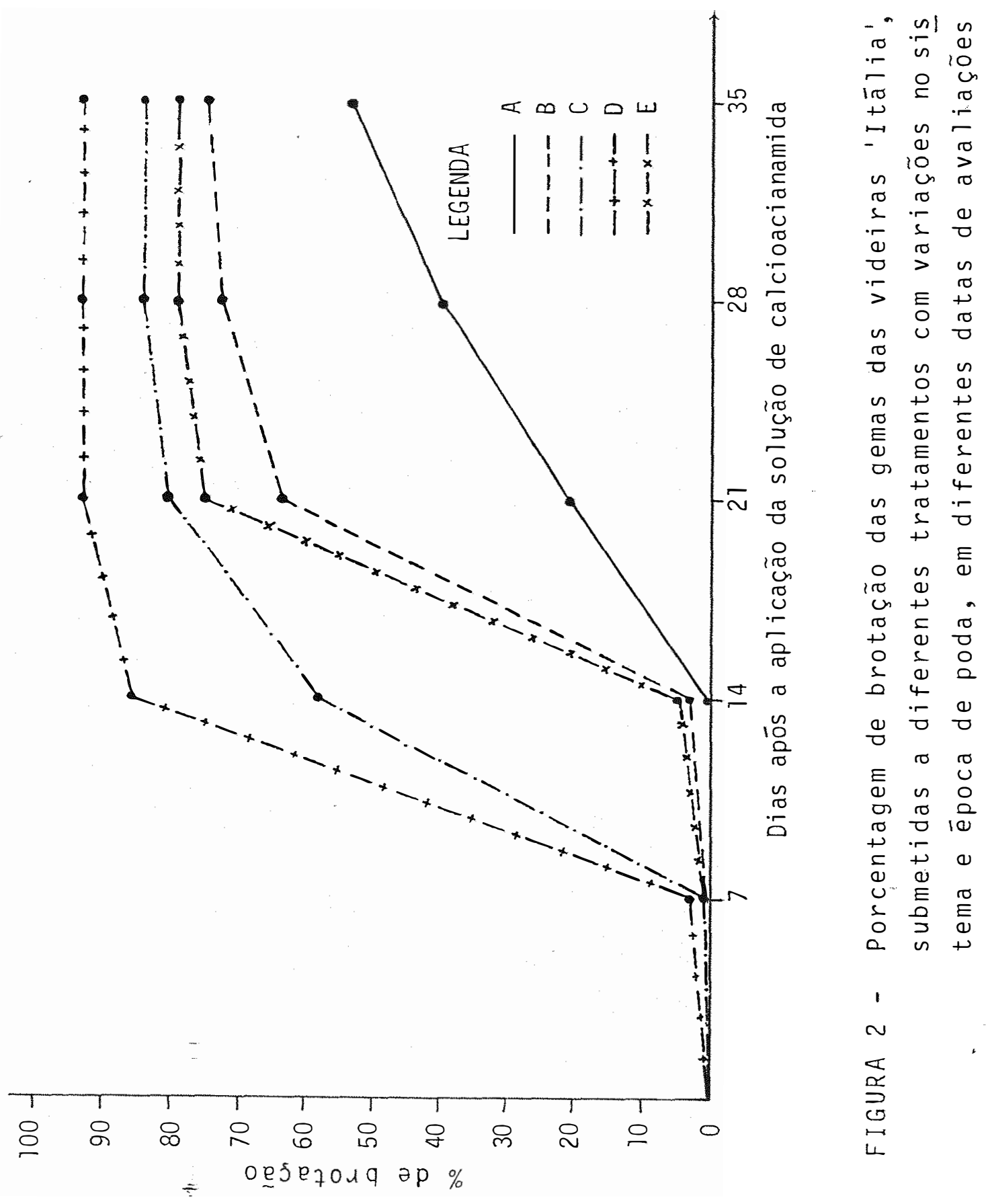




\section{3 - Efeitos sobre o número de Cachos Produzidos e Produ- GÃo POR Planta}

\subsection{1 - Nümero de Cachos Produzidos}

A anālise da variāncia do número de cachos prọ duzidos, revelou ocorrerem diferenças significativas entre os tratamentos, ao nível de $5 \%$ de probabilidade (Apêndice 5).

$$
\text { Pela Tabela } 3 \text {, observa-se que as plantas do }
$$

tratamento $B$ apresentaram maior número de cachos e as do tratamento $A$, menor nümero. As videiras dos tratamentos $A, B$, C , D e E apresentaram, respectivamente, $126,156,129$, 135 e 152 cachos por planta.

0 menor nümero de cachos produzidos no trata mento $A$, em relação aos demais, se deve à menor porcentagem de brotação (Figura 2).

A tendência na diminuição do nūmero de cachos produzidos nas plantas dos tratamentos $C$ e $D$ se deve, em parte, à eliminação daqueles severamente infectados pelo mîldioPZasmopara viticola (Berk. \& Curtis) Berl \& De Toni e pelo mo fo cinzento - Botrytis cinerea Pers. A incidência de doenças foi observada na fase pós-florescimento. Acredita-se que as plantas destes tratamentos apresentavam maior predisposição pa ra contrair as doenças naquela época, por apresentarem tecidos tenros ou estado nutricional deficiente como conseqüencia dos tratamentos, além de estarem localizadas juntamente com 
as plantas dos demais tratamentos, que poderiam ter servido de fonte de inōculo. A temperatura do ar, a umidade relativa e as precipitações pluviais registradas naquela época, também fa voreceram o desenvolvimento das doenças (Apēndice 2). Segundo KIMATI e GALLI (1980), o mîldio desenvolve-se bem em condí ções de alta umidade e calor, estando a temperatura ōtima para o desenvolvimento do fungo, situada entre 18 e $24^{\circ} \mathrm{C}$. 0 mo fo cinzento, segundo estes autores, desenvolve-se bem em condições de alta umidade e baixa temperatura.

\subsection{2 - Produção por Planta}

Para as produções obtidas por planta, a anāijse da variāncia mostrou existirem diferenças significativas en tre os tratamentos, ao nīvel de $1 \%$ de probabilidade (Apéndice 6) , com maiores produções para as plantas dos tratamentos A, $B$ e $E$, em relação às dos C e D (Tabela 3 ).

As produções obtidas nos tratamentos A, B, C, D e E foram, respectivamente, de $96.017,97.667,71.723$, 69.528 e 93.963 g por planta.

Nas plantas dos tratamentos $A$ e $E$, podadas, res pectivamente, em meados do inverno e na fase do inchamento das gemas, as produções foram equivalentes, concordando com os re sultados obtidos por LOOMIS (1943). 
No tratamento $B$, a variação no sistema de poda a inda não mostrou nenhum efeito negativo sobre a produção por planta, sendo a sua produtividade igual às dos tratamen tos $A$ e E. Neste tratamento, os brotos foram eliminados qua do apresentavam apenas 6 folhas, com $18,6 \mathrm{~cm}$ de comprimento. 0 peso da matéria seca dos brotos eliminados foi de somente 84 g por planta (Apēndice 4).

Os efeitos esgotantes dos tratamentos C e D so bre a produtividade das videiras foram evidentes, o que, de certa forma, concordam com os relatos de PUJOL (1972) e HIDAL GO (1979). Segundo eles, a poda realizada apōs a brotação das gemas tem efeito esgotante sobre a planta, sendo o seu de bilitamento maior quanto mais tardia e mais desenvolvidos os brotos. No Apéndice 4, observa-se que foram eliminados nos tratamentos C e D, respectivamente, brotos com 11 e 17 folhas, com 48,4 e 95,4 cm de comprimento e 309 e $1.453 \mathrm{~g}$ de matéria seca por planta. As plantas do tratamento D apresentavam - se na fase de plena floração por ocasião da eliminação dos brotos da extremidade do ramo.

A redução da produção nos tratamentos C e D, em parte, também se deve à incidéncia do mīldio e do mofo cinzen to, apōs a fase de florescimento. Os cachos e as bagas severamente afetados pelas doenças foram eliminados. A rachadura das bagas verificada nas fases pós-amolecimento e maturação do fruto, também contribuiu para diminuir a produção por planta. 
TABELA 3 - Número de cachos produzidos e produção por planta das videiras 'Itália', submetidas a diferentes tratamentos com variaçōes no sistema e época de poda

\begin{tabular}{lrr}
\hline $\begin{array}{l}\text { Trata- } \\
\text { mentos }\end{array}$ & $\begin{array}{l}\text { Número de cachos pro- } \\
\text { duzidos por planta }\end{array}$ & $\begin{array}{l}\text { Produção por } \\
\text { planta }\end{array}$ \\
\hline A & 126,00 b $(+)$ & $96.017,50 \mathrm{a}$ \\
B & $156,25 \mathrm{a}$ & $97.667,50 \mathrm{a}$ \\
C & $129,00 \mathrm{ab}$ & $71.723,75 \mathrm{~b}$ \\
D & $135,00 \mathrm{ab}$ & $69.528,75 \mathrm{~b}$ \\
E & $152,00 \mathrm{ab}$ & $93.963,75 \mathrm{a}$ \\
F Tratamentos & $4,75 *$ & $28,18 * *$ \\
C. V. (\%) & 8,99 & 6,11 \\
D.M.S. (5\%) & 28,31 & $11.823,24$ \\
\hline
\end{tabular}

$(+) \quad V a l o r e s$ seguidos de pelo menos uma letra igual não diferem entre si

(*) Significativo ao nível de $5 \%$ de probabilidade $\left({ }^{* *}\right)$ Significativo ao nível de $1 \%$ de probabilidade 


\section{4 - Efeitos sobre o Peso e Comprimento do Cacho}

\subsection{1-Peso do Cacho}

A anāitise da variància do peso do cacho acusou ocorrerem diferenças significativas entre os tratamentos, ao nivel de 1\% de probabilidade (Apēndice 7).

0 peso do cacho revelou-se maior no tratamento A e menor no tratamento D. Os tratamentos B, C e E não dife riram entre si. As videiras dos tratamentos $A, B, C, D$ e E produziram, respectivamente, cachos pesando $764,627,560$, 515 e 620 g (Tabela 4).

0 maior peso do cacho observado nas plantas do tratamento A foi devido ao menor nūmero de cachos produzidos por planta (Tabela 3), conseqüencia da baixa porcentagem de brotação (Figura 2). Este resultado é facilmente compreendido, pois, sendo menor o nümero de cachos produzidos por planta, a competição por assimilados entre eles diminui. Outra possível explicação seria a ocorrência de baixas temperaturas no inīcio do seu ciclo (Apēndice 2), que afetaram o crescimen to vegetativo, favorecendo o desenvolvimento dos rácimos.

0 menor peso do cacho obtido nas videiras submetidas ao tratamento $D$ se deve ao rigor do tratamento, onde os brotos foram efiminados na fase de plena floração, quando apresentavam 17 folhas e 95,4 cm de comprimento (Apéndice 4). 
Isso mostra o efeito debilitante da eliminação dos brotos jā bem desenvolvidos sobre o vigor das plantas, o que está de acordo com os relatos de PUJOL (1972) e HIDALGO (1979).

Nas plantas do tratamento $B$, o peso do cacho não foi afetado, certamente, por ser o tratamento ainda pouco drāstico. Os brotos foram eliminados quando apresentavam ape nas 6 folhas e $18,6 \mathrm{~cm}$ de comprimento (Apēndice 4). Nas plan tas do tratamento $C$, no entanto, jā se notou considerāvel efeito esgotante do tratamento realizado. Neste tratamento fo ram eliminados brotos com 11 folhas e $48,4 \mathrm{~cm}$ de comprimento (Apēndice 4).

A diminuição no peso do cacho nas plantas dos tratamentos C e D se deve, em parte, tambēm à eliminação de bagas infetadas pelo mîldio e mofo cinzento.

\section{5 .2 - Comprimento do Cacho}

Pela anālise da variāncia, o comprimento do ca cho apresentou diferenças entre os tratamentos, significati vos ao nível de $1 \%$ de probabilidade (Apēndice 8 ).

As plantas do tratamento A produziram cachos de maior comprimento e as do tratamento $D$, de menor comprimen to. Os comprimentos do cacho observados nos tratamentos A, B, C , D e E foram, respectivamente, de $26,1,26,0,24,6$, 22,6 e $25,0 \mathrm{~cm}$ (Tabela 4). 
56.

As discussões feitas para o "Peso do cacho" tam bēm são vālidas para este parāmetro.

TABELA 4 - Peso e comprimento dos cachos das videiras 'Itālia', submetidas a diferentes tratamentos com va riações no sistema e ēpoca de poda

\begin{tabular}{lcc}
\hline $\begin{array}{l}\text { Trata- } \\
\text { mentos }\end{array}$ & $\begin{array}{c}\text { Peso do cacho } \\
(\mathrm{g})\end{array}$ & $\begin{array}{c}\text { Comprimento do cacho } \\
(\mathrm{cm})\end{array}$ \\
\hline A & $764,63 \mathrm{a}(+)$ & $26,08 \mathrm{a}$ \\
B & $627,03 \mathrm{~b}$ & $25,98 \mathrm{ab}$ \\
C & $560,03 \mathrm{bc}$ & $24,65 \mathrm{~b}$ \\
D & $515,50 \mathrm{c}$ & $22,63 \mathrm{c}$ \\
E & $620,28 \mathrm{~b}$ & $25,05 \mathrm{ab}$ \\
--- Tratamentos & $18,05 * *$ & $20,34 * \star$ \\
F & 7,18 & 2,49 \\
C.V. (\%) & 99,93 & 1,39 \\
D.M.S. (5\%) &
\end{tabular}

(+) Valores seguidos de pelo menos uma letra igual não diferem entre si

$(* *)$ Significativo ao nivel de $7 \%$ de probabilidade 


\section{5 - Efeitos sobre os Parámetros da baga}

\subsection{1 - Nūmero de Sementes por Baga}

A anāitise da variāncia do nūmero de sementes por baga revelou existirem diferenças significativas entre os tratamentos, ao nível de $1 \%$ de probabilidade (Apēndice 9).

0 nümero de sementes mostrou-se superior nas bagas das videiras submetidas aos tratamentos A, B e E e menor naquelas submetidas ao tratamento $D$. Não foi observada diferença significativa entre os tratamentos $B$ e $C$. As bagas das plantas dos tratamentos A, B, C, D e E apresentaram, res pectivamente, $2,22,2,07,1,67,1,17$ e 2,23 sementes (Tabela 5).

0 baixo nūmero de sementes nas bagas do tratamento $D$ pode ser explicado, parcialmente, pela coincidéncia da plena floração com dias de chuvas persistentes, o que certa mente afetou o processo de polinização (Apēndice 2). Segundo Horticultural Education Association Committee (1961), citado por PETRI E PASQUAL (1980), o excesso de chuvas durante o florescimento pode lavar os grãos de póten do estigma ou diluị a secreção deste, não permitindo a germinação do pōlen.

Também pode provocar ruptura dos grãos de pólen devido a alta concentração de açūcar em seu interior. Em videira, segundo SOUSA (1969), dias quentes e claros sāo necessārios para a que da das corolas, e conseqüentemente, desabrochamento das flo- 
res. Provavelmente, o rigor do tratamento também tenha afeta do a porcentagem de germinação do pōlen e seu vigor. Conforme relatos de MARTINEZ-ZAPORTA (1964), o estado nutricional da planta não sō influi na porcentagem de germinação do pōlen, mas tambēm no seu vigor. Se as substāncias de reserva contidas nos gräos de pólen são insuficientes, o desenvolvimento do tubo polīnico é afetado e, como conseqüéncia, a fecundação é prejudicada. Isso tambēm explica, em parte, o baixo nümero de sementes nas bagas das videiras do tratamento $C$.

\subsection{2 - Peso da Baga}

Para este parāmetro, a añ̄ise da variāncia acusou existirem diferenças significativas entre os tratamen tos, ao nível de $1 \%$ de probabilidade (Apéndice 10).

Pela Tabela 5 , observa-se que as videiras dos tratamentos B e E produziram bagas de maior peso, seguidas pe las plantas dos tratamentos $A, C$ e $D$, em ordem decrescente de peso. As plantas do tratamento $D$ apresentaram cachos com bagas de menor peso. As plantas dos tratamentos A, B, C, D e E apresentaram, respectivamente, peso de 20 bagas de $227,7,240,0,210,7,187,7$ e $240,7 \mathrm{~g}$.

A tendēncia na diminuição do peso da baga nas plantas do tratamento $A$, comparativamente àquelas submetidas aos tratamentos $B$ e $E$, se deve ao maior nūmero de bagas dej- 
xados por cacho, por ocasião do desbaste.

Nos tratamentos C e D, a considerāvel diminui ção no peso da baga refiete a severidade da variação no siste ma de poda estudada (Apēndice 4). Outra possível explicação para o resultado seria o baixo nūmero de sementes encontrado nas bagas, conseqüéncia da polinizaçã̃o deficiente. Segundo WINKLER (1970), hā uma correlação direta entre o tamanho da ba ga e o nūmero de sementes nela contido. A semente é uma das fontes de auxina, necessāria ao desenvolvimento normal do fru to.

\subsection{3 - Comprimento da Baga}

A anāilise da variāncia do comprimento da baga revelou ocorrerem diferenças significativas entre os tratamen tos, ao nível de $1 \%$ de probabilidade (Apēndice 11).

As bagas das plantas submetidas aos tratamen tos $A, B$ e E apresentaram maior comprimento que aquelas dos tratamentos C e D. As videiras dos tratamentos A, B, C, D e E apresentaram, respectivamente, bagas com $30,7,31,2$, $29,6,29,8$ e $31,2 \mathrm{~mm}$ de comprimento (Tabela 5).

o comprimento da baga é função dos tratamentos executados e do nūmero de sementes, conforme jā discutidos no item "Peso da baga". 


\subsection{4 - Diāmetro da Baga}

Pela anālise da variāncia, observou-se ocorrerem diferenças significativas no diàmetro da baga entre os tra tamentos, ao nivel de $1 \%$ de probabilidade (Apēndice 12).

$$
\text { As plantas dos tratamentos A, B e E apresenta }
$$

ram bagas de maior diāmetro que as dos tratamentos $C$ e $D$. As bagas de menor diāmetro foram observadas nas videiras do tratamento D. Foram observados diāmetros da baga de 25,1, $25,2,24,2,22,8$ e $25,3 \mathrm{~mm}$, respectivamente, nas plantas sub metidas aos tratamentos A, B, C , D e E (Tabela 5).

o diāmetro da baga tambēm é função dos tratamentos executados e do número de sementes contido na baga, conforme já discutidos no îtem "Peso da baga". 
61.

TABELA 5 - Nūmero de sementes por baga e peso, comprimento e diāmetro das bagas das videiras 'Itālia', sub metidas a diferentes tratamentos com variações no sistema e época de poda

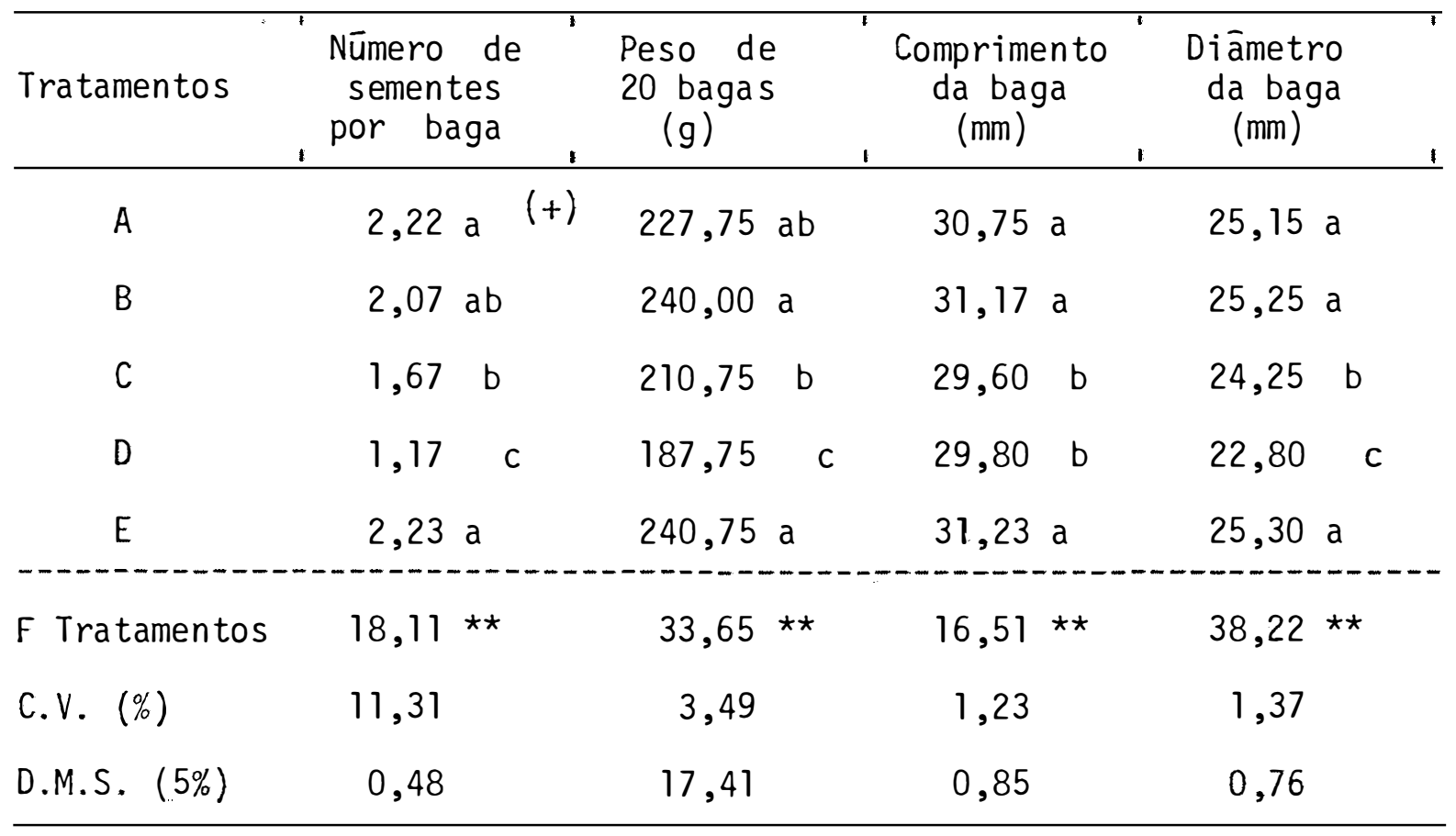

$(+)$ Valores seguidos de pelo menos uma letra igual não diferem entre si

(**) Significativo ao nivel de $1 \%$ de probabilidade 


\section{6 - Efeitos sobre o Vigor dos Ramos}

\subsection{1 - Comprimento do Ramo}

Pela anālise da variância, o comprimento do ra mo observado apresentou diferenças entre os tratamentos, significativas ao nível de $1 \%$ de probabilidade (Apéndice 13).

As plantas dos tratamentos A, B e E produziram ramos de maior comprimento que as dos demais, enquanto que as plantas do tratamento $C$ apresentaram ramos mais longos que as do tratamento D. O comprimento médio do ramo das videiras sub metidas aos tratamentos A, B, C, D e E foram, respectiva mente de 103,3,105,8,93,3,71,8 e 106,5 cm (Tabela 6).

Estes resultados mostram os efeitos esgotantes do tratamento $C$ e, principalmente, do D. Em videiras submeti dos a este tratamento, os brotos da extremidade dos ramos foram eliminados quando apresentavam 95,4 cm de comprimento, o que coincidiu com a fase de plena floração. No tratamento $C$ foram eliminados os brotos com $48,4 \mathrm{~cm}$ de comprimento (Apêndi ce 4). De certa forma, os resultados obtidos concordam com os relatos de PUJOL (1972) e HIDALGO (1979). Segundo eles, a poda realizada tardiamente após a brotação das gemas tem efeito debilitante sobre a planta, sendo seu debilitamento maior quanto mais tardia a poda e mais desenvolvidos os brotos. Nas plantas do tratamento B, cujos brotos foram eliminados quando apresentavam $18,6 \mathrm{~cm}$ de comprimento, ainda não 
foi observado nenhum efeito debilitante.

As podas realizadas em meados do inverno e no início do inchamento das gemas produziram os mesmos efeitos sobre o comprimento dos brotos.

\subsection{2 - Diàmetro do Ramo}

A anālise da variāncia do diāmetro do ramo revelou ocorrerem diferenças significativas entre os tratamen.tos, ao nível de 1\% de probabilidade (Apēndice 14).

0 diāmetro do ramo mostrou-se superior nas plan tas dos tratamentos $A$, B e E e menor naquelas dos tratamen tos $C$ e D. 0 tratamento $B$ não mostrou nenhum efeito debilitan te. As plantas dos tratamentos $A$ e $E$, submetidas à poda, respectivamente, em meados do inverno e no início do inchamento das gemas, apresentaram ramos de mesmo diāmetro. Os diāme tros médios dos ramos das videiras submetidas aos tratamentos $A, B, C, D$ e $E$ foram, respectivamente,de 10,8, 10,7, $9,5,8,9$ e $10,7 \mathrm{~mm}$ (Tabela 6).

\subsection{3 - Nümero de Entrenōs por Ramo}

Para este parāmetro, a anālise da variāncia re velou existirem diferenças significativas entre os tratamen tos, ao nivel de $1 \%$ de probabilidade (Apêndice 15). 
As plantas dos tratamentos A e E apresentaram nūmero superior de entrenōs por ramo, enquanto que as do tratamento $D$ apresentaram menor nūmero. Os nūmeros médios de entrenōs observados nos ramos das videiras submetidas aos trata mentos $A, B, C, D$ e $E$ foram, respectivamente, de 17,9 , $16,8,16,0,15,0$ e 17,7 (Tabe1a 6).

Cabe salientar que nas plantas dos tratamentos $A, B$ e $E$, que apresentaram ramos vigorosos, os brotos foram despontados uma semana antes do florescimento, ou seja, quando apresentavam, aproximadamente, 16 ou 17 folhas. Nas plantas submetidas aos tratamentos $C$ e $D$, principalmente naquelas do tratamento $D$, foi dispensado o desponte da maioria dos bro tos, devido ao seu desenvolvimento pouco vigoroso, conseqüēncia do esgotamento das substáncias de reserva provocado pelo rigor dos tratamentos (Apēndice 4 ).

\subsection{4 - Comprimento do Entrenō}

A anālise da variāncia do comprimento do entre nō revelou ocorrerem diferenças significativas entre os trat mentos, ao nível de $1 \%$ de probabilidade (Apēndice 16).

As plantas do tratamento B apresentaram entrenōs mais longos que as dos demais; e os de menor comprimento foram apresentados pelas plantas do tratamento $D$. Os tratamen tos $B, C$ e E não apresentaram diferenças significativas com re 
lação a este parāmetro, o mesmo acontecendo com os tratamentos A, C e E. Os comprimentos mëdios dos entrenós dos ramos das plantas submetidas aos tratamentos A, B, C , D e E foram, respectivamente, de $57,5,62,8,59,2,47,7$ e $60,3 \mathrm{~mm}$ (Ta bela 6$)$.

Os entrenós mais curtos, observados nas plantas do tratamento $A$, comparativamente às do tratamento $B$, se de ve à coincidencia do início do ciclo vegetativo com o período de temperaturas baixas (Apēndice 2). Muitos autores afirmam que a faixa ótima de temperatura para o desenvolvimento das plantas estā entre 25 e $30^{\circ} \mathrm{C}$. 
TABELA 6 - Comprimento e diāmetro do ramo, nūmero de entrenōs por ramo e comprimento do entrenó das videiras 'Itālia', submetidas a diferentes tratamen tos com variações no sistema e época de poda

\begin{tabular}{|c|c|c|c|c|}
\hline Tratamentos & $\begin{array}{l}\text { Comprimento } \\
\text { do ramo } \\
(\mathrm{cm})\end{array}$ & $\begin{array}{l}\text { Diāmetro } \\
\text { do ramo } \\
(\mathrm{mm})\end{array}$ & $\begin{array}{l}\text { Nūmero de } \\
\text { entrenōs } \\
\text { por ramo }\end{array}$ & $\begin{array}{l}\text { Comprimento } \\
\text { do entrenō } \\
(\mathrm{mm})\end{array}$ \\
\hline A & $103,30 \mathrm{a}^{(+)}$ & $10,80 \mathrm{a}$ & $17,95 \mathrm{a}$ & $57,52 \quad b$ \\
\hline B & $105,78 \mathrm{a}$ & $10,72 \mathrm{a}$ & $16,85 a b$ & $62,83 \mathrm{a}$ \\
\hline$c$ & $93,32 \quad b$ & $9,48 \quad b$ & $16,03 \mathrm{bc}$ & $59,18 a b$ \\
\hline D & $71,82 \quad c$ & $8,90 \quad b$ & $15,05 \quad c$ & $47,75 \quad c$ \\
\hline E & $106,55 a$ & $10,73 \mathrm{a}$ & 17,68 a & $60,30 \mathrm{ab}$ \\
\hline F Tratamentos & $65,71 * *$ & $16,07 * \star$ & $11,83 * *$ & $34,60 * \star$ \\
\hline c. V. $(\%)$ & 3,74 & 4,34 & 4,16 & 3,42 \\
\hline D.M.S. $(5 \%)$ & 8,12 & 0,99 & 1,57 & 4,44 \\
\hline
\end{tabular}

$(+)$ Valores seguidos de pelo menos uma letra igual não diferem entre si

(**) Significativo ao nível de $1 \%$ de probabilidade 


\section{7 - Efeitos sobre a Porcentagem de Desfolha}

As porcentagens de desfolha das videiras 'Itália', submetidas a diferentes tratamentos com variações no sis tema e ēpoca de poda, em diferentes datas de avaliações, encontram-se na Figura 3.

As avaliações foram iniciadas no dia 02/05/81, quando as videiras submetidas aos tratamentos $A, B, C, D$ e E apresentavam, respectivamente, $38,5,10,0,6,0,4,2$ e $10,0 \%$ de desfolha.

Naquela época, as plantas do tratamento A apre sentavam ramos visivelmente maduros, com folhas na fase de amarelecimento. As videiras submetidas aos tratamentos $B$ e E, apresentavam tambēm sarmentos maduros, porēm, as folhas eram mais esverdeadas. As plantas dos tratamentos C e D, princi palmente as do tratamento $D$, ainda mostravam grande parte da extremidade do ramo, com crescimento vegetativo.

Em plantas de todos os tratamentos observou-se desfolha progressiva con o decorrer do tempo, até que as foIhas foram atingidas pela geada no dia $18 / 06 / 81$, quando foi registrada a temperatura de $-1^{\circ} \mathrm{C}$, dentro do abrigo termomé trico (Apêndice 2). Nos tratamentos $C$ e $D$, as porções imatü ras dos ramos também foram afetadas. Na ūltima avaliação antes da geada (dia 13/06/81), os tratamentos $A, B, C, D$ e $E$ apresentavam $69,4,44,7,41,5,38,3$ e $44,7 \%$ de desfolha, 
68.

respectivamente. Na avaliação realizada no dia 27/06/81 jā foi constatada a desfolha completa das videiras, em todos os tratamentos estudados.

Espera-se, desta forma, que as plantas do tratamento A tenham acumulado maior quantidade de substāncias de reserva que as dos tratamentos $B$ e $E$, e estas, mais que as dos tratamentos C e D. A desfolha precoce provocada pela gea da, provavelmente, influirá no comportamento das videiras dos diferentes tratamentos, na safra vindoura. 


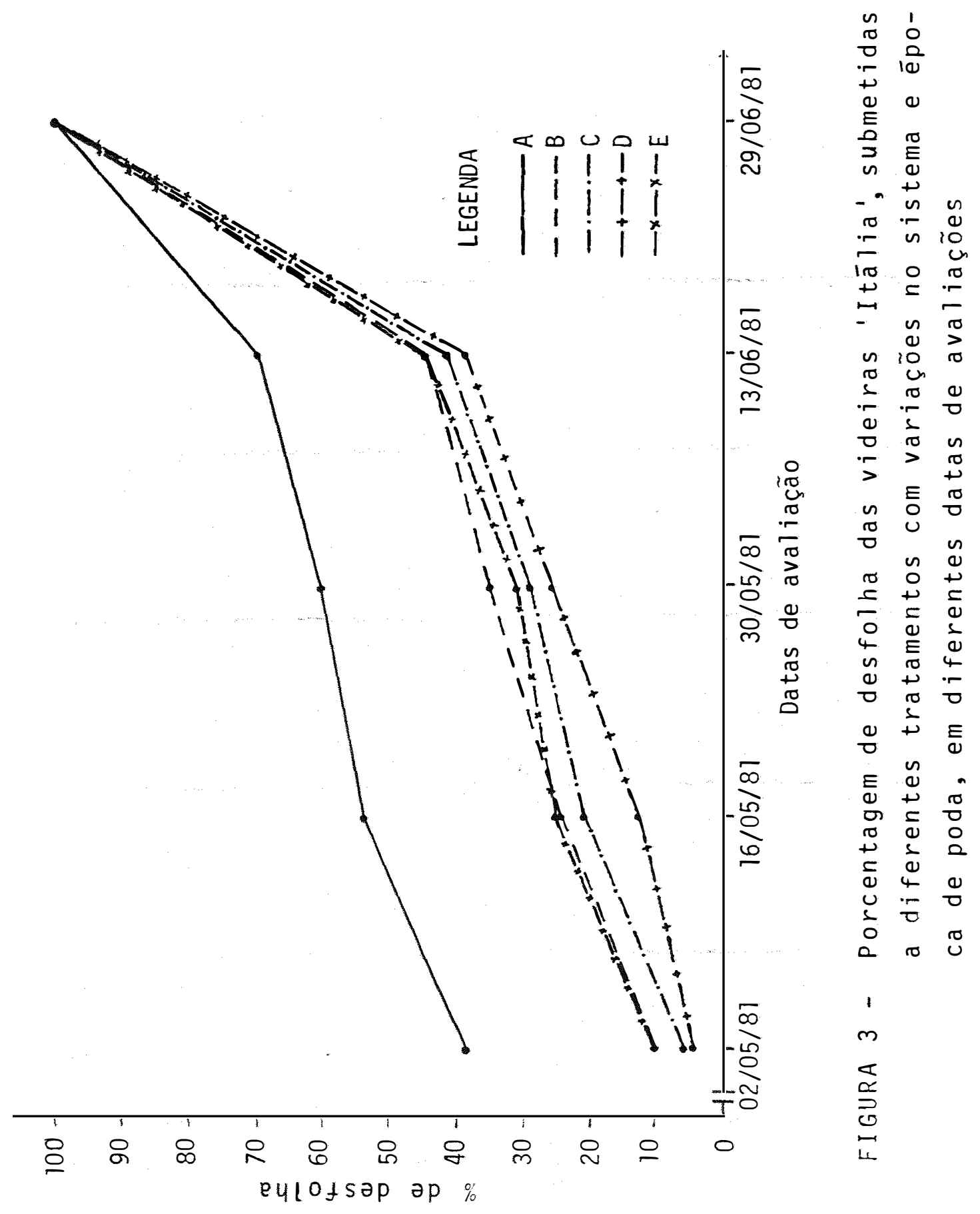




\section{5 - CONCLUSÕES}

Nas condições em que foi conduzido o experimen to, os resultados obtidos permitem concluir o seguinte:

a - 0 ciclo vegetativo foi mais longo nas videiras 'Itālia', podadas em meados do inverno, em relação àquelas podadas mais tardiamente.

b - A uniformidade e a porcentagem de brotação das gemas aumentaram, à medida que se atrasou a época da poda, independentemente dos tratamentos executados.

c - A variação no sistema de poda estudada atrasou em 44 dias a maturação da uva, em relação à poda executada em meados do inverno e, em 16 dias, comparativamente à poda rea lizada no início do inchamento das gemas. 
d - A poda realizada no início do inchamento das gemas atrasou em 28 dias a maturação da uva, em relação à poda exe cutada em meados do inverno.

e - Na variação do sistema de poda estudada, a eliminação dos brotos com $20 \mathrm{~cm}$ de comprimento não afetou a produtivida de, os parāmetros dos cachos e das bagas e o vigor dos ra mos. A eliminação dos brotos com $50 \mathrm{~cm}$ e $100 \mathrm{~cm}$ de comprimento, resultou em prejuizos para os mesmos parámetros.

f - As videiras podadas em meados do inverno e no início do inchamento das gemas apresentaram produtividade, comprimento dos cachos, parāmetros das bagas e vigor dos brotos equivalentes. As plantas podadas em meados do inverno produziram cachos de maior peso.

$g$ - A maturação dos ramos foi retardada com atraso no início do ciclo vegetativo da planta, ficando os mesmos sujeitos aos riscos das geadas.

h - A incidéncia de doenças fūngicas aumentou, à medida que se atrasou o início do ciclo vegetativo da videira.

i - A ocorréncia de rachadura das bagas aumentou, à medida que se atrasou o periodo de maturação da uva. 


\section{6 - LITERATURA CITADA}

ALCALDE, A. J. ; M. POUDOU ; M. NAZRALA e H. MARTINEZ, 1973. Intensidad de poda en vid. Idia, (303): 31-40.

ANUARIO ESTATISTICO DO BRASIL, 1980. Rio de Janeiro, Fundação IBGE, 41]: 365-366.

BALASUBRAHMANYAM, V. R. e S. D. KHANDUJA, 1977.a. Effect of varying cane lengths on the fruiting potential of Gulabi vines. Indian J. Hort., 34(3): 225-228.

BALASUBRAHMANYAM, V. R. e S. D. KHANDUJA, 1977.b. Effect of varying cane lengths on the fruiting potential of Thompson Seedless vines. Indian J. Hort., 34(2): 113-116.

BHUJBAL, B. G., 1972. The effect of levels of pruning on bud sprouting,yield and quality in Thompson Seedless grape (Vitis vinifera L.). Indian J. Hort., 29(3/4): 298-301. 
BOLCEV, A., 1972. Influence de la taille et de la charge en yeux sur la quantité et la qualité de la récolte du cépage Italia. Horticultural and Viticultural Science, 9 (3): 95 101. (Resumo).

BOLETIM MENSAL CEAGESP; 1978/1980. São Paulo, CEAGESP/De partamento de Economia, Serviço de Estatística.

CAWTHON, D. L. e J.R. MORRIS, 1977. Yield and quality of 'Concord' grapes as affected by pruning severity, nodes per bearing unit, training system, shoot positioning, and sampling date in Arkansas. d. Amer. Soc. Hort. Sci., 102(6): $760-767$.

CHANANA, Y. R. e H. KUMAR, 1974. Pruning studies on Sultani na grape (Vitis vinifera L.). Indian J. Hort., 31(2): $165-166$.

CENTRO NACIONAL DE ENSINO E PESQUisAs AGRONŌMICAS. Comissão de Solos, 1960. Levantamento de reconhecimento dos solos do Estado de São Paulo. Rio de Janeiro, Serviço Nacional de Pesquisas Agronómicas. 634 p. (Boletim, 12).

EMMERSON, J. G. e L. E. POWEL, 1978. Endogenous abscisic acid in relation to rest and burst in three Vitis species. J. Amer. Soc. Hort. Sci., 103(5): 677-680.

GALSTON, A. W. e P. J. DAVIES, 1972. Mecanismo de controle no desenvolvimento vegetal. São Paulo, Edgard Blücher, EDUSP. $171 \mathrm{p}$.

HIDALGO, L., 1979. La poda de la vid. Barcelona, MundiPrensa. 199 p. 
IWASAKI, K., 1980. Effects of bud scale removal, calcium cyanamide, $\mathrm{GA}_{3}$, and ethephon on bud break of 'Muscat of Alexandria' grape (Vitis vinifera L.). J. Jap. Soc. Hort. Sci., 48(4): 395-398.

IWASAKI, K. e R. J. WEAVER, 1977. Effects of chilling, calcium cyanamide, and bud scale removal on bud break, rooting, and inhibitor content of buds of 'Zinfandel' grape (Vitis vinifera L.). J. Amer. Soc. Hort. Sci., 102(5): $584-587$.

KHANDUJA, S. D. ; V. R. BALASUBRAHMANYAM e K. B. SARASWAT, 1976. Effect of varying cane lengths on fruiting potential of Beauty Seedless vines. Indian J. Hort., 33(2): $127-$ 129.

KIMATI, H. e F. GALLI, 1980. Doenças da videira - Vitis spp. In: GALLI, F., 1980. Manual de Fitopatologia; doenças das plantas cultivadas. São Paulo, Ceres. v. 2 , p. 574-587.

KISHINO, A. Y. ; M. MASHIMA ; S. L. C. de CARVALHO ; E. C. do NASCIMENTO e A. CATANEO, 1978.a. Efeito da calc ocianami da na brotação da videira cultivar Itālia (Pirovano 65). In: CONGRESSO BRASILEIRO DE FRUTICULTURA, 4 , Salvador, 1977. Anais. Cruz das Almas, Sociedade Brasileira de Fru ticultura. p. 315-324.

KISHINO, A. Y. ; E. C. dO NASCIMENTO ; M. TSUNETA ; S: L. C. de CARVALHO e M. MASHIMA; 1978.b. Considerações sobre o uso da calciocianamida visando estimular a brotação da vi. deira. Londrina, IAPAR. (Informe da Pesquisa, 7 ). 
KISHINO, A. Y. e M. MASHIMA, 1980. Uva. In: FUNDAÇÃO INSTITUTO AGRONÔMICO DO PARANA. Manual Agropecuārio para o Paranā, 1980. Londrina. P. 139-177.

KLIEWER, W. M., 1975. Effect of root temperature on budbreak, shoot growth, and fruit-set of 'Cabernet Sauvignon' grapevines. Amer. J. Enol. Vitic., 26(2): 82-89.

KOBAYASHI, A. ; T. HOSOI; H. INOUE E H. YUKINAGA, 1965. Root activity and suitable application time of nitrogen in the dormant period of grapes. J. Jap. Soc. Hort. Sci., 34 (4): $291-296$.

KUBOTA, N. ; T. KIMURA e K. SHIMAMURA, 1979. Effect of root temperature on budbreak and shoot growth of potted vines of cultivar Muscat of Alexandria heated as from December or February. Scientific Reports of the Faculty of Agriculture, Okayama University, (53): 1-9.

KUROI, I., 1974. Studies on the growth promotion of grape vines by the lime nitrogen treatments during the rest period. Memoirs of the Faculty of Agriculture, Niigata University, (12): 1-71.

KUROI, I. ; Y. SHIRAISHI e S. IMANO, 1963. Studies on breaking the dormancy of grapevines. I. Effects of lime nitro gen treatment for shortening the rest period of glass house grown grapevine. J. Jap. Soc. Hort. Sci., 32: 175180 .

LANE, R. P., 1977. Yield of young muscadine grapes as affec ted by cane pruning. J. Amer. Soc. Hort. Sci., 102(4): $379-380$. 
LIDER, L. A. ; A. N. KASIMATIS e W. M. KLIEWER, 1973. Effect of pruning severity and rootstock on growth and yield of two grafted, cane-pruned wine grape cultivars. J. Amer. Soc. Hort. Sci., 98(1): 8-12.

LOOMIS, N. H., 1943. The influence of time and method of pruning on yields of muscadine grapes. Proc. Amer. Soc. Hort. Sci., 42: 418-420.

MAGOON, C. A. e I. W. DIX, 1943. Observations on the response of grape vines to winter temperatures as related to their dormancy requirements. Proc. Amer. Soc. Hort. Sci., 42: 407-412.

MALAVOLTA, E., 1967. Manual de química agricola; adubos e adubação. São Paulo, Ceres. $606 \mathrm{p}$.

MANEY, T. J. e H. H. PLAGGE, 1934. A study of production and physiology of Concord grape vines as affected by variations in the severity of pruning. Proc. Amer. Soc. Hort. Sci., 32: $\quad 392-396$.

MARTINEZ-ZAPORTA, F., 1964. Fruticultura; fundamentos e prácticas. Madrid, Instituto Nacional de Investigaciones Agronomicas. $1.003 \mathrm{p}$.

MASHIMA, M., 1973. Novas técnicas na cultura da uva Itālia. In: CONGRESSO BRASILEIRO DE FRUTICULTURA, 2 , Viçosa. 1973. Anais. Campinas, Sociedade Brasileira de Fruticultura. p. 521-527. 
METIVIER, J. R., 1979. Dormência e germinação. In: FERRI, M. G., 1979. Fisiologia vegetal. 2. São Paulo, EPU, EDUSP. p. 343-392.

MORIMOTO, F. e K. KUMASHIRO, 1978. Studies on the resttreaking of buds of deciduous fruit trees by chemical treatment. Journal of the Faculty of Agriculture, Shinshu University, 15(1): 1-18.

NARAWONGSANONT, A., 1975. The influence of number of hours of chilling at $43^{\circ} \mathrm{F}$ on breaking the rest period of dormant vines of six cultivars of the muscadine, (Vitis rotundifoZia, Michx.). Mississipi, Mississipi State University. (Thesis - MS).

NITSCH, J. P., 1963. The mediation of climatic effects through endogenous regulating substances. In: EVANS, L. T., 1963. Environmental control of plant growth. New York, Academic Press. p. 175-193.

NUNES, R. F. de M. ; J. A. S. ALBUQUERQUE e 0. P. ARAGAO, 1979. Efeito de tipos de poda na produção de videira, cul tivar Piróvano 65 (Vitis vinifera L.), no Vale do São Fran cisco. In: CONGRESSO BRASILEIRO DE FRUTICULTURA, 5 , Pe1otas, 1979. Anais. Pelotas, Sociedade Brasileira de Fru ticultura. p. 698-707.

PARTRIDGE, N. L., 1921. A note on the fruiting habit of the Concord grape. Proc. Amer. Soc. Hort. Sci., 18: 193-196. 
PEREIRA, F. M. e J. C. OLIVEIRA, 1978. Efeitos de diferen tes formas de aplicação de calciocianamida sobre a antecipação da brotação e da época de produção da cultivar de vị deira Niagara Rosada. Científica, 6(2): 203-207.

PETRI, J. L. e M. PASQUAL, 1980. Polinização da macieira no Alto Rio do Peixe, Santa Catarina. Florianópolis, EMPASC/ DID. 40 p. (EMPASC. Boletim Técnico, 1).

PUJOL, J. N., 1972. Viticultura practica. Lerida, Dilagro. $370 \mathrm{p}$.

SALISBURY, F. B. e C. ROSS, 1969. Plant physiology, Belmont, Wadsworth Publishing Company. $747 \mathrm{p}$.

SAMISH, R. M:, 1954. Dormancy in woody plants. Ann. Rev. Plant Physiol., 5: 183-204.

SAMPAI0, J. M. M., 1973. Influēncia do clima na produção da videira (Vitis vinifera L.). In: CONGRESSO BRASILEIRO, DE FRUTICULTURA, 2 , Viçosa, 1973. Anais. Campinas, Socie dade Brasileira de Fruticultura. p. 513-520.

SINGHROT, R. S. ; J. P. SINGH e 0. P. GUPTA, 1977. Effect of pruning levels on productiveness of Thompson Seedless cultivar of grapes (Vitis vinifera L.). Haryana J. Hort. Sci., $6(1 / 2): 37-40$.

SOUSA, J. S. I. de, 1969. Uvas para o Brasil. São Paulo, Melhoramentos. $454 \mathrm{p}$. 
TICO, L. e J. TICO, 1972. Cómo ganar dinero con el cultivo de la vid. Barcelona, Cedel. 264 p.

TOMKINS, J. e SHAULIS, N., 1955. The Catawba grape in New york. II. Some effects of severity of pruning on the production of fruit and wood. Proc. Amer. Soc. Hort. Sci., 66: $214-219$.

WAREING, P. F., 1954. Growth studies in woody species. VI. The locus of photoperiodic perception in relation to dormancy. Physiol. Plant, 7: 261-277.

WAREING, P. F., 1956. Photoperiodism in woody plants. Ann. Rev. Plant Physiol., 7: 191-214.

WINKLER, A. J., 1970. Viticultura. México, Continental. $792 \mathrm{p}$. 

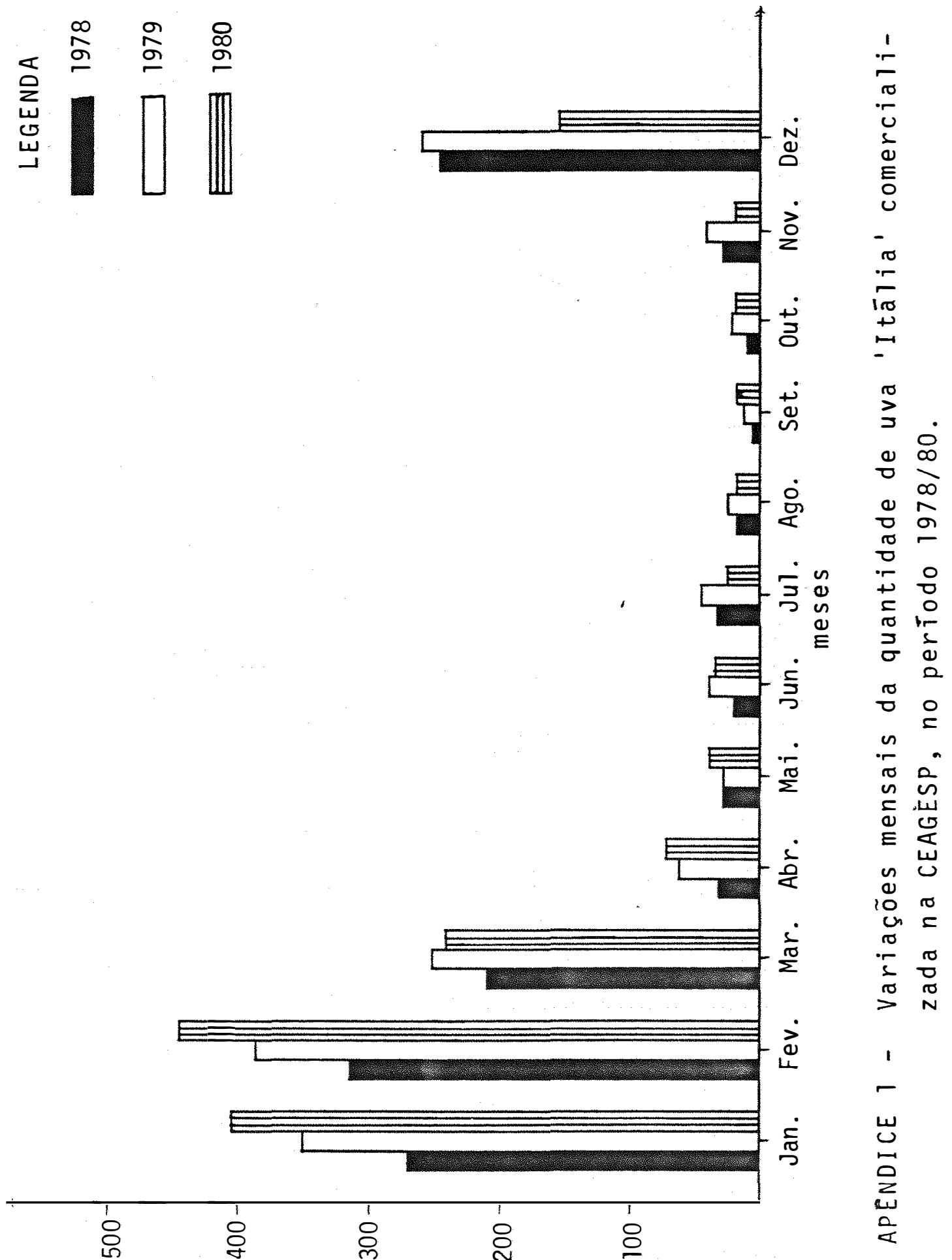

(6y 8 әр sex!es $000^{\circ} 1$ ) apep!queno 
APENDICE 2 - Temperaturas, umidade relativa do ar e precipitação pluvial do período agosto de 1980 a ju nho de 1981. São Miguel Arcanjo, SP (latitude $23^{\circ} 50^{\prime} \mathrm{s}$, longitude $47^{\circ} 54^{\prime} \mathrm{W}$ e altitude $700 \mathrm{~m}$ )

\begin{tabular}{|c|c|c|c|c|c|c|c|c|}
\hline \multirow{2}{*}{$\begin{array}{l}\text { Mès / } \\
\text { Ano }\end{array}$} & \multirow{2}{*}{ Década } & \multicolumn{5}{|c|}{ Temperatura $\left({ }^{\circ} \mathrm{C}\right)$} & \multirow{2}{*}{$\begin{array}{l}\text { Umidade } \\
\text { relativa } \\
(\overline{\mathrm{m}} \%)\end{array}$} & \multirow{2}{*}{$\begin{array}{l}\text { Preci- } \\
\text { pitação } \\
\text { pluvial } \\
(\mathrm{mm})\end{array}$} \\
\hline & & Média & $\begin{array}{l}\text { Média } \\
\text { mãxima }\end{array}$ & $\begin{array}{l}\text { Mēdia } \\
\text { minima }\end{array}$ & $\begin{array}{l}\text { Māxima } \\
\text { absol. }\end{array}$ & $\begin{array}{l}\text { Minima } \\
\text { absol. }\end{array}$ & & \\
\hline Ago. /80 & $\begin{array}{l}1_{a}^{a} \\
2_{a}^{a} \\
3 .\end{array}$ & $\begin{array}{l}15,0 \\
16,7 \\
16,1\end{array}$ & $\begin{array}{l}21,5 \\
24,1 \\
22,1\end{array}$ & $\begin{array}{l}10,3 \\
12,1 \\
11,5\end{array}$ & $\begin{array}{l}26,3 \\
31,0 \\
29,2\end{array}$ & $\begin{array}{l}6,4 \\
4,0 \\
9,1\end{array}$ & $\begin{array}{l}81,7 \\
83,4 \\
81,7\end{array}$ & $\begin{array}{r}12,5 \\
9,5 \\
11,0\end{array}$ \\
\hline Set. $/ 80$ & $\begin{array}{l}1_{a}^{a} \\
2_{a}^{a} \\
3 .\end{array}$ & $\begin{array}{l}16,4 \\
15,9 \\
13,8\end{array}$ & $\begin{array}{l}23,0 \\
20,5 \\
20,1\end{array}$ & $\begin{array}{r}10,8 \\
12,4 \\
8,9\end{array}$ & $\begin{array}{l}28,0 \\
26,0 \\
27,3\end{array}$ & $\begin{array}{l}5,9 \\
5,8 \\
3,2\end{array}$ & $\begin{array}{l}81,1 \\
83,7 \\
79,9\end{array}$ & $\begin{array}{l}10,3 \\
23,0 \\
32,5\end{array}$ \\
\hline Out./80 & $\begin{array}{l}1^{\mathrm{a}} \\
2^{\mathrm{a}} \\
3^{\mathrm{a}}\end{array}$ & $\begin{array}{l}16,8 \\
18,4 \\
21,0\end{array}$ & $\begin{array}{l}23,1 \\
24,8 \\
28,5\end{array}$ & $\begin{array}{l}12,3 \\
13,7 \\
15,7\end{array}$ & $\begin{array}{l}31,0 \\
33,0 \\
35,0\end{array}$ & $\begin{array}{r}9,9 \\
12,0 \\
13,5\end{array}$ & $\begin{array}{l}80,6 \\
79,5 \\
79,5\end{array}$ & $\begin{array}{l}11,0 \\
12,4 \\
61,4\end{array}$ \\
\hline Nov./80 & $\begin{array}{l}1^{a} \\
2^{a} \\
3 .\end{array}$ & $\begin{array}{l}20,1 \\
18,7 \\
20,5\end{array}$ & $\begin{array}{l}26,6 \\
25,3 \\
25,8\end{array}$ & $\begin{array}{l}15,9 \\
14,1 \\
16,2\end{array}$ & $\begin{array}{l}32,0 \\
31,4 \\
32,0\end{array}$ & $\begin{array}{l}12,0 \\
11,0 \\
14,4\end{array}$ & $\begin{array}{l}80,4 \\
81,5 \\
84,1\end{array}$ & $\begin{array}{r}25,6 \\
2,6 \\
35,6\end{array}$ \\
\hline Dez./80 & $\begin{array}{l}7^{a} \\
2^{a} \\
3 a\end{array}$ & $\begin{array}{l}21,9 \\
23,2 \\
21,9\end{array}$ & $\begin{array}{l}27,4 \\
29,7 \\
27,4\end{array}$ & $\begin{array}{l}17,6 \\
18,2 \\
18,3\end{array}$ & $\begin{array}{l}32,2 \\
32,0 \\
28,5\end{array}$ & $\begin{array}{l}15,0 \\
16,0 \\
16,5\end{array}$ & $\begin{array}{l}84,3 \\
76,4 \\
84,3\end{array}$ & $\begin{array}{r}42,5 \\
108,7 \\
72,5\end{array}$ \\
\hline Jan./81 & $\begin{array}{l}1 \\
1^{a} \\
3 \\
3\end{array}$ & $\begin{array}{l}22,0 \\
22,4 \\
22,3\end{array}$ & $\begin{array}{l}27,6 \\
27,9 \\
28,5\end{array}$ & $\begin{array}{l}17,9 \\
18,9 \\
18,0\end{array}$ & $\begin{array}{l}30,0 \\
35,0 \\
33,0\end{array}$ & $\begin{array}{l}13,4 \\
17,5 \\
15,5\end{array}$ & $\begin{array}{l}83,9 \\
86,3 \\
82,0\end{array}$ & $\begin{array}{r}80,5 \\
144,5 \\
57,2\end{array}$ \\
\hline Fev./81 & $\begin{array}{l}7^{\mathrm{a}} \\
2^{\mathrm{a}} \\
3 \\
3\end{array}$ & $\begin{array}{l}23,6 \\
23,2 \\
23,2\end{array}$ & $\begin{array}{l}30,5 \\
30,7 \\
31,2\end{array}$ & $\begin{array}{l}18,9 \\
18,3 \\
17,3\end{array}$ & $\begin{array}{l}33,5 \\
33,0 \\
34,0\end{array}$ & $\begin{array}{l}17,0 \\
16,1 \\
15,0\end{array}$ & $\begin{array}{l}80,4 \\
79,6 \\
78,7\end{array}$ & $\begin{array}{l}52,2 \\
16,0 \\
42,1\end{array}$ \\
\hline
\end{tabular}


APENDICE 2 - Continuação

\begin{tabular}{|c|c|c|c|c|c|c|c|c|}
\hline \multirow{2}{*}{$\begin{array}{l}\text { Mēs/ } \\
\text { Ano }\end{array}$} & \multirow{2}{*}{ Década } & \multicolumn{5}{|c|}{ Temperatura $\left({ }^{\circ} \mathrm{C}\right)$} & \multirow{2}{*}{$\begin{array}{c}\text { Umidade } \\
\text { relativa } \\
(\hat{\mathrm{m}} \%)\end{array}$} & \multirow{2}{*}{$\begin{array}{l}\text { Preci- } \\
\text { pitação } \\
\text { pluvial } \\
(\mathrm{mm})\end{array}$} \\
\hline & & Média & $\begin{array}{l}\text { Média } \\
\text { mâxima }\end{array}$ & $\begin{array}{l}\text { Média } \\
\text { mĩnima }\end{array}$ & $\begin{array}{l}\text { Māxima } \\
\text { absol. }\end{array}$ & $\begin{array}{l}\text { Minima } \\
\text { absol. }\end{array}$ & & \\
\hline Mar. /81 & $\begin{array}{l}1^{a} \\
2^{a} \\
3 .\end{array}$ & $\begin{array}{l}23,1 \\
21,9 \\
20,4\end{array}$ & $\begin{array}{l}29,9 \\
28,8 \\
26,1\end{array}$ & $\begin{array}{l}18,4 \\
16,7 \\
16,3\end{array}$ & $\begin{array}{l}35,0 \\
33,2 \\
29,0\end{array}$ & $\begin{array}{l}15,9 \\
14,0 \\
13,0\end{array}$ & $\begin{array}{l}81,0 \\
81,8 \\
83,9\end{array}$ & $\begin{array}{r}3,7 \\
75,0 \\
29,0\end{array}$ \\
\hline $\mathrm{Abr} . / 81$ & $\begin{array}{l}1_{a}^{a} \\
2 \dot{a} \\
3 \dot{a}\end{array}$ & $\begin{array}{l}19,7 \\
17,9 \\
18,5\end{array}$ & $\begin{array}{l}26,6 \\
24,2 \\
24,8\end{array}$ & $\begin{array}{l}14,6 \\
13,6 \\
13,8\end{array}$ & $\begin{array}{l}30,0 \\
27,1 \\
27,8\end{array}$ & $\begin{array}{r}11,8 \\
11,0 \\
9,1\end{array}$ & $\begin{array}{l}82,4 \\
82,5 \\
82,9\end{array}$ & $\begin{array}{r}1,5 \\
29,0 \\
44,0\end{array}$ \\
\hline Mai./81 & $\begin{array}{l}1 \\
2 \mathfrak{a} \\
3 \\
3\end{array}$ & $\begin{array}{l}18,5 \\
18,7 \\
17,5\end{array}$ & $\begin{array}{l}25,8 \\
26,2 \\
23,9\end{array}$ & $\begin{array}{l}12,5 \\
13,0 \\
12,6\end{array}$ & $\begin{array}{l}28,4 \\
29,0 \\
25,4\end{array}$ & $\begin{array}{r}8,0 \\
10,0 \\
7,9\end{array}$ & $\begin{array}{l}82,5 \\
80,2 \\
81,9\end{array}$ & $\begin{array}{r}10,0 \\
6,0 \\
0,0\end{array}$ \\
\hline Jun. /81 & $\begin{array}{l}l^{a} \\
2 a \\
3 \\
3\end{array}$ & $\begin{array}{l}14,9 \\
13,1 \\
15,0\end{array}$ & $\begin{array}{l}20,6 \\
19,4 \\
23,2\end{array}$ & $\begin{array}{r}10,3 \\
7,8 \\
8,8\end{array}$ & $\begin{array}{l}25,5 \\
24,0 \\
25,0\end{array}$ & $\begin{array}{r}5,0 \\
-\quad 1,0 \\
7,0\end{array}$ & $\begin{array}{l}82,6 \\
79,4 \\
76,9\end{array}$ & $\begin{array}{r}24,2 \\
17,5 \\
0,0\end{array}$ \\
\hline
\end{tabular}


APENDICE 3 - Resultados das anālises quĩmica e física do solo da ārea experimental

\begin{tabular}{lrrr}
\hline & \multicolumn{3}{c}{ Profundidade $(\mathrm{cm})$} \\
\cline { 2 - 4 } & $0-20$ & $20-40$ & $40-60$ \\
\hline $\mathrm{pH}(\mathrm{em}$ àgua $)$ & 5,80 & 5,00 & 5,10 \\
$\mathrm{Al}^{+3}(\mathrm{me} / 100 \mathrm{~g})$ & 0,00 & 0,68 & 0,39 \\
$\mathrm{Ca}^{+2}(\mathrm{me} / 100 \mathrm{~g})$ & 4,00 & 3,42 & 3,70 \\
$\mathrm{Mg}^{+2}(\mathrm{me} / 100 \mathrm{~g})$ & 2,42 & 2,09 & 1,97 \\
$\mathrm{~K}^{+}(\mathrm{me} / 100 \mathrm{~g})$ & 0,12 & 0,11 & 0,22 \\
$\mathrm{P} \quad(\mathrm{ppm})$ & 3,40 & 9,50 & 2,10 \\
$\mathrm{C}(\%)$ & 1,58 & 2,27 & 1,96 \\
Argila (\%) & 64,00 & 62,00 & 60,00 \\
Silte (\%) & 11,00 & 9,00 & 12,00 \\
Areia (\%) & 25,00 & 29,00 & 28,00 \\
\hline
\end{tabular}


APENDICE 4 - Nūmero e comprimento dos brotos, nūmero de folhas por broto e peso da matéria seca dos brotos eliminados das videiras 'Itālia', submetidas a diferentes tratamentos com variações no sistema e época de poda

\begin{tabular}{|c|c|c|c|c|}
\hline Tratamento & $\begin{array}{l}\text { Número de } \\
\text { brotos eli- } \\
\text { minados por } \\
\text { planta }\end{array}$ & $\begin{array}{l}\text { Comprimento } \\
\text { do broto } \\
(\mathrm{cm})\end{array}$ & $\begin{array}{l}\text { Nümero de } \\
\text { folhas por } \\
\text { broto }\end{array}$ & $\begin{array}{l}\text { Peso de ma } \\
\text { téria secá } \\
\text { por planta } \\
\text { (g) }\end{array}$ \\
\hline A & -- & -- & -- & -- \\
\hline B & 58,0 & 18,6 & 6,0 & 84,0 \\
\hline C & 58,5 & 48,4 & 11,0 & 309,0 \\
\hline$D^{(t)}$ & 78,5 & 95,4 & 17,0 & $1.453,0$ \\
\hline$E$ & -- & -- & -- & -- \\
\hline
\end{tabular}

(+) Os brotos foram eliminados na fase de plena floração 
APENDICE 5 - Anālise da variāncia do nūmero de cachos de uva 'Itālia' produzido por planta, nos diferentes tratamentos com variações no sistema e época de poda

\begin{tabular}{lccc}
\hline Causas de Variação & G. L. & Q.M. & F \\
\hline Tratamentos & 4 & 749,4500 & $4,75 *$ \\
Blocos & 3 & 239,7832 & \\
Resíduo & 12 & 157,6166 & \\
\hline Total & 19 & & \\
\hline
\end{tabular}

(*) Significativo ao nivel de $5 \%$ de probabilidade C. V. $=8,99 \%$

APENDICE 6 - Anālise da variāncia da produção por planta de uva 'Itālia', nos diferentes tratamentos com va riações no sistema e ēpoca de poda

\begin{tabular}{|c|c|c|c|}
\hline Causas de Variação & G. L. & Q. M. & $\mathrm{F}$ \\
\hline Tratamentos & 4 & $774.774 .112,50$ & $28,18 \star \star$ \\
\hline Blocos & 3 & $49.086 .080,06$ & \\
\hline Resĩduo & 12 & $27.490 .336,02$ & \\
\hline Total & 19 & & \\
\hline
\end{tabular}

(**) Significativo ao nível de $1 \%$ de probabilidade C.V. $=6,11 \%$ 
APENDICE 7 - Anālise da variāncia do peso do cacho de uva 'Itālia', nos diferentes tratamentos com variações no sistema e época de poda

\begin{tabular}{|c|c|c|c|}
\hline Causas de Variação & G. L. & Q. M. & $F$ \\
\hline Tratamentos & 4 & $35.451,5703$ & $18,05 \star \star$ \\
\hline Blocos & 3 & 969,5442 & \\
\hline Resĩduo & 12 & $1.963,9674$ & \\
\hline Total & 19 & & \\
\hline $\begin{array}{ll}\left({ }^{*}\right) & \text { Significativ } \\
& \text { C.V. }=7,18 \%\end{array}$ & ao nî & de $1 \%$ de prol & dade \\
\hline
\end{tabular}

APENDICE 8 - Anālise da variāncia do comprimento do cacho de uva 'Itália', nos diferentes tratamentos com variações no sistema e época de poda

\begin{tabular}{lccc}
\hline Causas de Variação & G. L. & Q. M. & F \\
\hline Tratamentos & 4 & 7,7937 & $20,34 * *$ \\
Blocos & 3 & 0,1351 & \\
Residuo & 12 & 0,3830 & \\
\hline \multicolumn{1}{c}{ Total } & 19 & & \\
\hline
\end{tabular}

(**) Significativo ao nivel de $1 \%$ de probabilidade C. $V .=2,49 \%$ 
APENDICE 9 - Anālise da variāncia do nūmero de sementes por baga de uva 'Itālia', nos diferentes tratamentos com variações no sistema e época de poda

\begin{tabular}{lccc}
\hline Causas de Variação & G. L. & Q. M. & F \\
\hline Tratamento & 4 & 0,8150 & $18,15 * \star$ \\
Blocos & 3 & 0,0125 & \\
Residuo & 12 & 0,0449 & \\
\hline \multicolumn{1}{c}{ Total } & 19 & & \\
\hline
\end{tabular}

$(* *)$ Significativo ao nível de $1 \%$ de probabilidade C. $V .=11,31 \%$

APENDICE 10 - Anālise da variāncia do peso da baga de uva 'Itālia', nos diferentes tratamentos com va riações no sistema e época de poda

\begin{tabular}{lrrr}
\hline Causas de Variação & G. L. & Q. M. & F \\
\hline Tratamentos & 4 & $2.006,4499$ & $33,65 \star \star$ \\
Blocos & 3 & 38,5333 & \\
Residuo & 12 & 59,6166 & \\
\hline \multicolumn{1}{c}{ Total } & 19 & & \\
\hline
\end{tabular}

(**) Significativo ao nível de $1 \%$ de probabilidade C. V. $=3,49 \%$ 
APENDICE 11 - Anālise da variāncia do comprimento da baga de uva 'Itālia', nos diferentes tratamentos com variações no sistema e época de poda

\begin{tabular}{lccc}
\hline Causas de Variação & G. L. & Q. M. & F \\
\hline Tratamentos & 4 & 2,3432 & 16,51 ** \\
Blocos & 3 & 0,2673 & \\
Resíduo & 12 & 0,1419 & \\
\hline \multicolumn{1}{c}{ Total } & 19 & & \\
\hline
\end{tabular}

(**) Significativo ao nível de $1 \%$ de probabilidade C. V. $=1,23 \%$

APENDICE 12 - Anālise da variāncia do diāmetro da baga de uva 'Itālia', nos diferentes tratamentos com variações no sistema e época de poda

\begin{tabular}{lccc}
\hline Causas de Variação & G. L. & Q. M. & F \\
\hline Tratamentos & 4 & 4,3070 & $38,25 * *$ \\
Blocos & 3 & 0,1218 & \\
Residuo & 12 & 0,1126 & \\
\hline \multicolumn{1}{c}{ Total } & 19 & & \\
\hline
\end{tabular}

(**) Significativo ao nível de $1 \%$ de probabilidade C. V. $=1,37 \%$ 
APENDICE 13 - Anālise da variāncia do comprimento do ramo da videira 'Itālia', nos diferentes trata mentos com variações no sistema e época de poda

\begin{tabular}{lcrc}
\hline Causa de Variação & G. L. & Q. M. & F \\
\hline Tratamentos & 4 & 851,6094 & 65,71 ** \\
Blocos & 3 & 46,5873 & \\
Residuo & 12 & 12,9591 & \\
\hline Total & 19 & & \\
\hline
\end{tabular}

(**) Significativo ao nível de $1 \%$ de probabilidade C.V. $=3,74 \%$

APENDICE 14 - Anālise da variāncia do diāmetro do ramo da videira 'Itālia', nos diferentes tratamen tos com variações no sistema e época de poda

\begin{tabular}{lccc}
\hline Causa de Variação & G. L. & Q. M. & F \\
\hline Tratamentos & 4 & 3,0987 & $16,08 * *$ \\
Blocos & 3 & 0,3698 & \\
Resíduo & 12 & 0,1927 & \\
\hline \multicolumn{1}{c}{ Total } & 19 & & \\
\hline
\end{tabular}

(**) Significativo ao nīvel de $1 \%$ de probabilidade C. $V .=4,34 \%$ 
APENDICE 15 - Anālise da variância do nūmero de entrenōs por ramo da videira 'Itālia', nos diferentes trata mentos com variações no sistema e época de poda

\begin{tabular}{lccc}
\hline Causa de Variação & G. L. & Q. M. & $F$ \\
\hline Tratamentos & 4 & 5,7132 & $11,83 * *$ \\
Blocos & 3 & 0,3966 & \\
Residuo & 12 & 0,4829 & \\
\hline Total & 19 & & \\
\hline
\end{tabular}

(**) Significativo ao nível de $1 \%$ de probabilidade C. V. $=4,16 \%$

APENDICE 16 - Anālise da variância do comprimento do entrenó da videira 'Itālia', nos diferentes tratamen tos com variações no sistema e época de poda

\begin{tabular}{|c|c|c|c|}
\hline Causa de Variação & G L L. & Q. M. & $F$. \\
\hline Tratamentos & 4 & 134,0633 & $34,60 \star \star$ \\
\hline Blocos & 3 & 11,3153 & \\
\hline Residuo & 12 & 3,8738 & \\
\hline Total & 19 & & \\
\hline
\end{tabular}

(**) Significativo ao nível de $1 \%$ de probabilidade C. $v$. $=3,42 \%$ 